\title{
Petrographic characteristics and paleoenvironmental history of Eocene lignites of Cambay basin, Western India
}

\author{
Prakash K. Singh ${ }^{1} \cdot$ Vijay K. Singh ${ }^{1} \cdot$ M. P. Singh ${ }^{1} \cdot$ P. K. Rajak ${ }^{1}$
}

Received: 5 February 2017/Revised: 5 April 2017/Accepted: 24 June 2017/Published online: 10 July 2017

(C) The Author(s) 2017. This article is an open access publication

\begin{abstract}
Lignite samples collected from Vastan, Rajpardi and Tadkeshwar lignite mines of Cambay basin (Gujarat) were subjected to organic petrographic investigations and geochemical analyses and the data, thus generated, is used to reconstruct the paleodepositional history of these lignite sequences. The lignites of Cambay basin dominantly comprise huminite maceral group (71.6\%-86.3\%) followed by liptinite (10.1\%-19.3\%) and inertinite (3.6\%-11.0\%) maceral groups. The mineral matter varies from $9.0 \%$ to $20.0 \%$. The petrography based facies model indicates that these lignites have high values of gelification index (GI) and low tissue preservation index revealing a continuous wet condition in the basin and a relatively slower rate of subsidence during the decay of organic matter. On several occasions, during the formation of seams in Tadkeshwar, Rajpardi and Vastan mines, the value of GI exceeded 10 which indicates a forest permanently flooded and the cause of pronounced degree of degradation. However, few sections in Tadkeshwar seam had relatively drier spells of environmental conditions due to fluctuation in the water table as revealed by moderately high content of inertinite macerals. This is specially indicated by the occurrence of funginite which normally thrives in the upper oxygenated peatigenic layer and indicates prevalence of oxic conditions during plant deposition. Such conditions prevailed during a transgressive phase but there were intermittent fluvial activities also giving rise to supratidal flood plain as reflected in the form of associated carbonaceous shales in the basin.
\end{abstract}

Keywords Cambay basin $\cdot$ Western India $\cdot$ Lignite $\cdot$ Maceral $\cdot$ Paleodepositional environment

\section{Introduction}

In Gujarat, the lignite deposits are found mainly in Cambay Basin (Tadkeshwar, Rajpardi and Vastan lignite mines), Kachchh Basin (Panandhro and Matanomadh lignite mines) and Saurashtra Basin (Bhavnagar lignite mine). Cambay Basin is located in the northwest part of the Indian craton, covering an area of $59,000 \mathrm{~km}^{2}$, with a length of 425 and $13 \mathrm{~km}$ wide in the central part. It extends from $21^{\circ}$ to $25^{\circ} \mathrm{N}$ latitudes and $71^{\circ} 15^{\prime}$ to $73^{\circ} 30^{\prime} \mathrm{E}$ longitudes in the state of

Prakash K. Singh

prakashbhu@ rediffmail.com

1 Coal and Organic Petrology Lab, Centre of Advanced Study in Geology, Banaras Hindu University, Varanasi, Uttar Pradesh 221005, India
Gujarat and partly in Rajasthan (Pandey et al. 1993). The lignite seams in this region lie unconformable on the weathered trap on lithomargic clay. ${ }^{1}$ There is almost $200 \mathrm{~m}$ thick muddy succession in Vastan lignite field which has been differentiated into three stratigraphic units- succession$\mathrm{A}$, succession-B and succession-C. They directly lie over the Deccan traps. The $45 \mathrm{~m}$ thick succession-A is the lignite bearing and consists of greenish grey shales, carbonaceous shales and shell carbonates apart from lignite (Garg et al. 2008). Mc Cann (2010) considers the shell rich beds (carbonate facies) as Chenier ridge. Further, he believes that the carbonaceous shale litho-facies and the greenish grey shale litho-facies are part of mudstone facies. Prasad et al. (2013) found the carbonaceous shale litho-facies to be associated

\footnotetext{
$\overline{1}$ Lithomargic clay is normally fine grained, brown in color and amorphous in nature.
} 
with the lignite litho-facies and linked them to marsh land; and considered the greenish grey shale facies formed under bay environment. They have shown that successions $\mathrm{B}$ and $\mathrm{C}$ essentially comprise of mud which are deposited in supratidal mudflats under dry condition.

Geologically, these deposits belong to Eocene age (Saxena 1979; Singh and Singh 2005; Balasubramanyan 2006; Sahni et al. 2006; Singh et al. 2010a, b, 2012a, b, 2016a, b). Lignites, along with mud rich sediments and siderites from Rajpardi, Vastan, and Tadkeshwar, were deposited in a predominantly low-energy, near-shore/coastal setting as confirmed by McCann (2010). Presence of shales along with lignite seams also indicates intermittent fluvial activities (Singh et al. 2010a, b; Prasad et al. 2013). Home et al. (1978) have discussed the cyclic occurrence of coal and marine and nonmarine biota successively in the younger beds. It would be interesting to see the position of Cambay basin closer to equator during the Early Eocene period. The northward drift of Indian Plate during Cretaceous to Eocene period is shown in Fig. 1a. Considerable work on sedimentation, stratigraphy, structures and depositional environments of the Tertiary sediments has been carried out by ONGC in Surat and Bharuch districts. Significant contributions, in this respect, have also been made by Rao (1969), Sudhakar and Basu (1973), Dutta et al. (2011). Some important references on the study of coals and lignites of Gujarat include those of Saxena (1979); Pareek (1981); Singh and Singh (2003, 2005); Sahni et al. 2006; Joshi (2007); Singh et al. (2010a); Thakur et al. (2010); Dutta et al. (2011); Singh (2012) and Rao et al. (2013). Studies carried out so far have shown that a significant Tertiary hydrocarbon belt extends through the Sanchor-Mehsana-Ahmedabad-Tarapur-Broach-Surat regions of Gujarat which continues further to the Barmer region of Rajasthan (Mathur et al. 1968; Biswas 1987, 1992). Nevertheless, further study is required to understand the hydrocarbon potential of this region and its controls.

Lignite, when exposed to the atmosphere develops cracks and splits into small pieces due to moisture loss. It contains resin patches, pyrite and minerals such as marcasite, siderite and chalcopyrite. The focus of the present research work encompasses the lignite deposits of the Cambay basin of Gujarat in a view to understand the petrological and geochemical attributes of the lignite deposits of Gujarat, because very little petrological data exists about these lignites as compared to the wealth of literature available on Indian Gondwana coals.

\section{Geology of Cambay basin}

The Cambay Basin, situated in the northwestern part of Indian craton, is a narrow elongated rift-graben which came in to existence as a result of rifting in the early
Paleocene. Saurashtra craton lies on the west of Cambay Basin while Aravalli is located in the northeast, and Deccan lies in the southeast. It extends from a little north of Sanchor to the south in Cambay Gulf and ultimately opens into Arabian Sea. On the west and east, it is bounded by basin margin faults. It extends upto Viramgram and Gogha in the west while Himmatnagar-Baroda and Rajpipla lie near its eastern margin (Pandey et al. 1993). Based on the major basement fault, Cambay Basin is sub-divided into five blocks (Mathur et al. 1968) which are listed from north to south as Sanchor Patan Block, Mehsana-Ahmedabad Block, Tarapur-Cambay Block, Jambusar-Broach Block, and Narmada Tapti Block.

The Quaternary sediments cover the major part of the Cambay basin. The beddings generally trend towards N-E and S-W with gentle dip. Tertiary sediments are not profound in this basin but occur in Gogha-Bhavnagar and Jhagadia-Tarkeswar areas. The Tertiary rocks in this region consist of sandstone, conglomerate, clay limestone, lignite ranging in age from early Eocene to early Miocene. The major litho units include Babaguru Formation underlain by the Tadkeshwar Formation which, in turn, is underlain by Nummulitic Formation. The Tadkeshwar Formation comprises the lignites in form of lenses having variable thickness and lateral extent. The lignite producing mines of Cambay Basin are mainly located in the southern part of Narmada-Tapti block. The younger Cambay Shale/Tadkeshwar Formation comprises the lignite bearing horizons and the shales are good source rock for oil and gas in the basin. The lignite seams are often associated with greenish grey shales, carbonaceous shales and shell-carbonates (Garg et al. 2008). At the bottom lies the grey clay-bed, which is continuous with varying thickness and is overlain by carbonaceous clay-bed. Sand lenses, sandstone, carbonaceous clay and lignite are reported to occur embedded in grey clay. The carbonaceous clay bed is conformably overlain by a thick lignite seam, which is a marker bed. The lignite seam is soft, friable and brown containing yellow resin and pockets of clay. The lignite seam is conformably succeeded by upper carbonaceous clay. The grey, plastic, bentonitic clay lies over upper carbonaceous clay (GMDC 1989). There is an increase in the proportion of sand towards the upper portion of the bentonitic clay and gradually converts into sandy clay. Two unconformities are reported in the area, one between the Traps and Vagadkhol Formation, and the other between the lower clays and upper sands of the Tadkeshwar Formation. Borehole data indicates the presence of two persistent lignite seams designated respectively as top (0.15-8.8 $\mathrm{m}$ thick) and bottom (1.0-3.4 $\mathrm{m}$ thick) seams/horizons. In addition to them, a few non mineable and uneconomic local seams also occur in this area. The sub-surface occurrence of coal/lignite in Gujarat extends from Tharad in the North to Mahisagar 

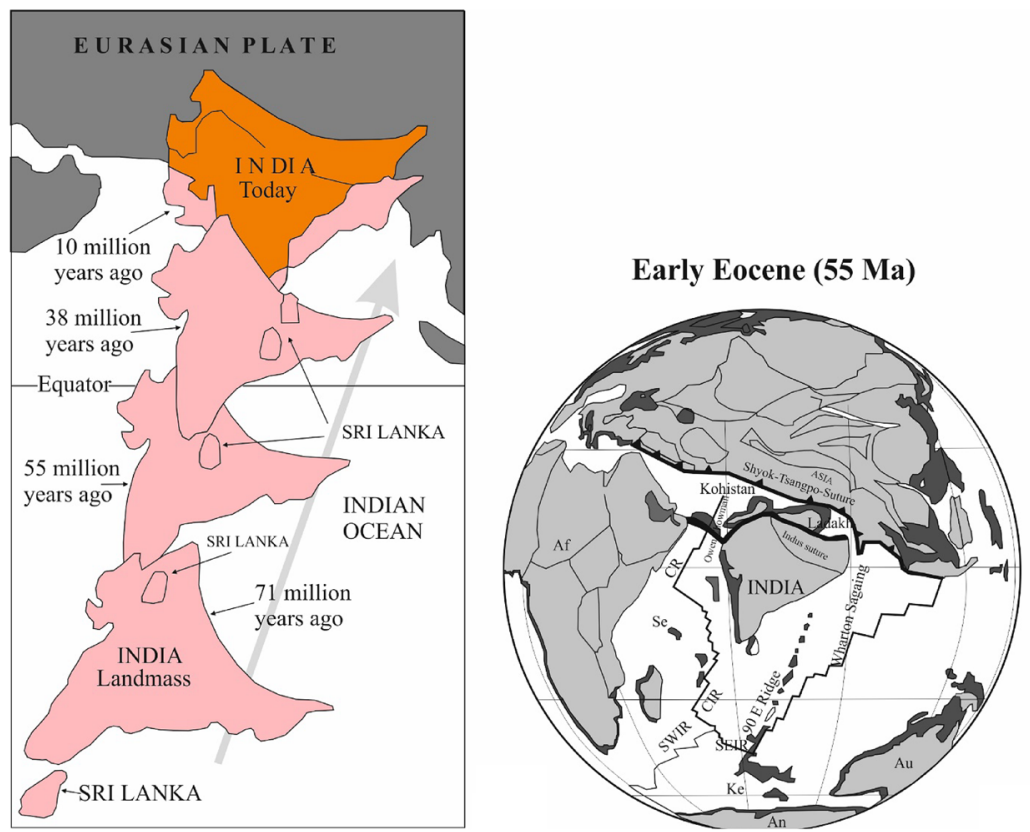

(a)

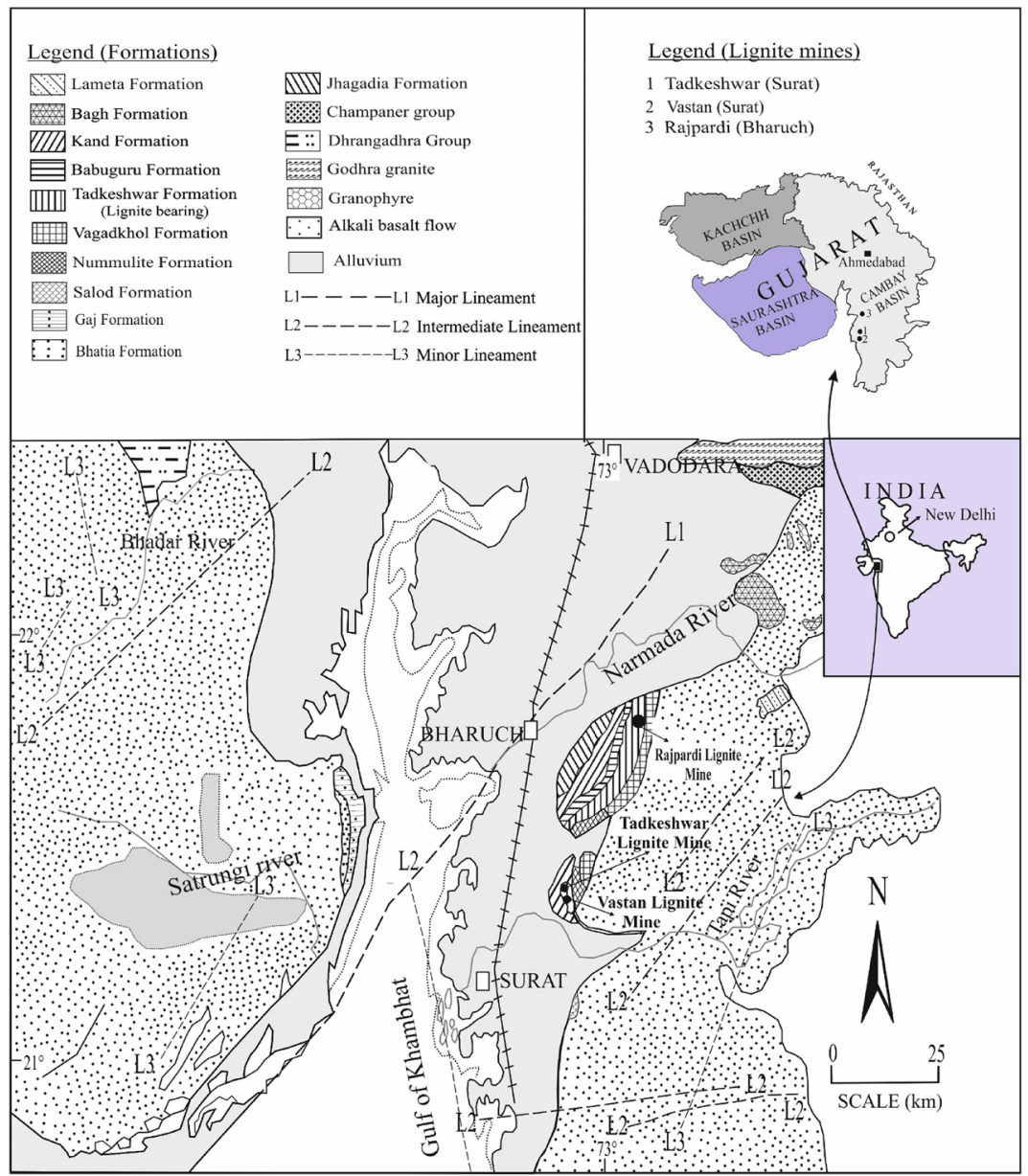

(b)

Fig.1 a Shifting of Indian plate during last 71 million years (left); location of India during Eocene period (right); after Chatterjee and Bajpai (2016). b Geological map of Cambay Basin and location of lignite fields (redrawn from, GSI 2012) 
Table 1 General Stratigraphic succession in the Cambay Basin, Gujarat (after Pandey et al. 1993)

\begin{tabular}{|c|c|c|c|c|}
\hline Sl. no. & Age & Formation & Lithology & $\begin{array}{l}\text { Thickness } \\
(\mathrm{m})\end{array}$ \\
\hline 1 & Pleistocene to Recent & Alluvium & Varied colored sands, soil and Kankar & - \\
\hline 2 & Middle Miocene to Pliocene & Jhagadia Formation & Light colored sand stones, marls, limestone and conglomerate & 304 \\
\hline 3 & Lower Miocene & Kand Formation & $\begin{array}{l}\text { Limestone, marl sand clays with sandstone bearing } \\
\text { conglomerate }\end{array}$ & 457 \\
\hline 4 & Lower most Miocene & Babaguru Formation & $\begin{array}{l}\text { Ferruginous sandstone, agate bearing conglomerates and varied } \\
\text { clay, gray sandstone and white sands }\end{array}$ & 152 \\
\hline 5 & Oligocene to Upper Eocene & $\begin{array}{l}\text { Tadkeshwar }^{\mathrm{a}} \\
\text { Formation }\end{array}$ & $\begin{array}{l}\text { Grey, yellow and brown friable sandstone with clay lenses. } \\
\text { Bentonitic clays with lignite bed and lenses of carbonaceous } \\
\text { clays sandstone and lignite }\end{array}$ & 152 \\
\hline 6 & Upper Eocene to Lower Eocene & Numulitic Formation & Numulitic limestone, clays with sandstone lenses & 122 \\
\hline 7 & Lower Eocene & Vagadkhal Formation & Bentonitic clays, frable sandstone and conglomerates & 304 \\
\hline 8 & Cretaceous & Deccan Traps & Basalts with basic intrusive & - \\
\hline
\end{tabular}

${ }^{a}$ Now established as Early Eocene in age (Sahni et al. 2006)

River in the South. Along the Saurashtra coast and to the east of the Gulf of Cambay, the basin spreads as a thin strip comprising $75-150 \mathrm{~m}$ thick beds of greenish and whitish grey and black clay/shales with lignite seams. The Cambay lignites have been studied by Bajpai et al. (2005), Singh (2012), Singh et al. (2010a, 2012a) and Prasad et al. (2013). The geological map of Cambay basin is shown in Fig. 1b and the details of the geological succession of the basin are given in Tables 1, 2 and 3.

Table 2 Major lithounits of the Tadkeshwar Formation based on the borehole logs (GMDC 1989)

\begin{tabular}{ll}
\hline Babaguru formation & Agate Conglomerate \\
& Ferruginous Sandstone \\
& Sand clay \\
& Grey clay \\
& Lignite \\
& Carbonaceous clay \\
& Lenses of sandstone \\
& Carbonaceous clay \\
& Lignite \\
& Grey clay \\
& Nummulitic Limestone \\
\hline
\end{tabular}

\section{Method of study}

In the present investigation, the lignite samples were collected from all the working mines of Cambay Basin (Tadkeshwar, Rajpardi and Vastan) of Gujarat (Fig. 1b). Every precaution was taken to collect fresh coal samples from the various sections in stratigraphic order. The coal sampling was done following the Pillar Sampling Method. The vertical seam profile was reconstructed and megascopic variations in the coals were studied. For petrographic studies and geochemical analysis the coal samples, were crushed to -18 mesh size and -70 mesh size respectively. For microscopic examination, the lignite samples were crushed and particulate mounts were polished. The maceral analysis was performed on the polished mounts under reflected light using a Leitz Orthoplan-Pol Microscope equipped with Wild Photoautomat MPS 45 in the Coal and Organic Petrology Laboratory, Department of Geology, Banaras Hindu University. The line-to-line and point-topoint spacing was maintained at $0.4 \mathrm{~mm}$ and more than 600 counts were taken on each sample. The methodology given by Taylor et al. (1998) was adopted; huminite macerals were termed and described as per ICCP-1994 (Sýkorová et al. 2005), liptinite macerals have been identified as per

Table 3 Stratigraphic succession in the Vastan lignite mine of Cambay Basin (after Bhandari et al. 2005)

\begin{tabular}{lll}
\hline Formation & Lithology & Age \\
\hline $\begin{array}{l}\text { Alluvium/Black soil } \\
\text { Amrawati }\end{array}$ & Soil and Recent alluviumNummulitic limestone and marl & Recent and SubRecent \\
& Calcareous bentonitic variegated Clay, unfossiliferous & Late Eocene \\
Cambay Shale/Tadkeshwar & $\begin{array}{c}\text { Greenish grey, whitish clayand brown fissile shale, clayand marl with carbonaceous } \\
\text { zone including lignite seam with vertebrate, plant, pollen and spore fossils }\end{array}$ & Early Eocene \\
Vagadkhol & Variegated clay & Palaeocene-EarlyEocene \\
Deccan Trap & Basalt & Late Cretaceous \\
\hline
\end{tabular}


ICCP system-1994 (Pickel et al. 2017) while ICCP (2001) was followed for the nomenclature of inertinite macerals.

In the present study, the indices, gelification index (GI) and tissue preservation index (TPI), have been taken from Flores (2002) which is a modified version of Kalkreuth et al. (1991), for brown coals and the calculations are as per the following formulae:

$$
\begin{aligned}
\mathrm{GI}= & (\text { huminite }+ \text { macrinite }) / \\
& (\text { fusinite }+ \text { semifusinite }+ \text { inertodetrinite }) \\
\mathrm{TPI}= & (\text { telohuminite }+ \text { fusinite }+ \text { semifusinite }) / \\
& (\text { gelinite }+ \text { macrinite }+ \text { inertodetrinite } \\
& + \text { detrohuminite })
\end{aligned}
$$

The micro and mega-petrographic profiles were constructed for various seams in order to understand the variation in the nature and quality of lignite from bottom to top of different coal seams. The megascopic characters and group maceral composition of these lignites have been used by Singh et al. (2016a, b) as provided in Tables 4, 5 and 6 while discussing the geochemistry of selected trace elements of these lignites. The set of data has also been used here for discussing their paleomire. The reflectance measurement has been performed on huminite macerals especially ulminite grains. Help has been taken from Jennifer et al. (2013) for rank study. The proximate analysis was carried out as per BIS 2003.

\section{Result and discussion}

Macroscopically, the lignites of Cambay basin are gen-

\begin{tabular}{|c|c|c|c|c|c|c|c|c|c|}
\hline \multirow[t]{2}{*}{$\begin{array}{l}\text { S. } \\
\text { no. }\end{array}$} & & \multirow[t]{2}{*}{$\begin{array}{l}\text { Sample } \\
\text { no. }\end{array}$} & \multirow[t]{2}{*}{ Megascopic characteristics } & \multirow{2}{*}{$\begin{array}{l}\text { Humi } \\
\text { (vol\%) }\end{array}$} & \multirow{2}{*}{$\begin{array}{l}\text { Lipt } \\
(\mathrm{vol} \%)\end{array}$} & \multirow{2}{*}{$\begin{array}{l}\text { Inert } \\
\text { (vol\%) }\end{array}$} & \multicolumn{2}{|c|}{$\begin{array}{l}\text { Mineral } \\
\text { Matter } \\
\text { (vol\%) }\end{array}$} & \multirow[t]{2}{*}{$\begin{array}{l}\text { Ash } \\
\text { yield } \\
\text { (wt\%) }\end{array}$} \\
\hline & & & & & & & Pyrite & Other & \\
\hline 1 & $\begin{array}{l}\text { Vastan upper } \\
\text { lignite seam }\end{array}$ & V11 & $\begin{array}{l}\text { Unstratified, matrix rich, brown inhomogeneous } \\
\text { lignite }\end{array}$ & 68.79 & 9.54 & 12.13 & 3.98 & 5.57 & 4.18 \\
\hline 2 & & V10 & $\begin{array}{l}\text { Unstratified, matrix rich, brown inhomogeneous } \\
\text { lignite with presence of sulphur }\end{array}$ & 65.20 & 12.60 & 15.60 & 4.8 & 1.8 & 4.35 \\
\hline 3 & & V9 & $\begin{array}{l}\text { Stratified, matrix rich, brown inhomogeneous lignite } \\
\text { with presence of sulphur }\end{array}$ & 80.64 & 9.18 & 1.80 & 3.79 & 4.59 & 5.88 \\
\hline 4 & & V8 & $\begin{array}{l}\text { Unstratified, matrix rich, brown inhomogeneous } \\
\text { lignite with presence of sulphur }\end{array}$ & 67.27 & 13.17 & 9.38 & 7.39 & 2.79 & 4.68 \\
\hline 5 & & V7 & Unstratified, matrix rich, black inhomogeneous lignite & 69.64 & 9.33 & 8.33 & 11.31 & 1.39 & 4.61 \\
\hline 6 & & V6 & Stratified, matrix rich, brown inhomogeneous lignite & 67.80 & 9.00 & 9.20 & 12.4 & 1.60 & 4.50 \\
\hline 7 & & V5 & Unstratified, matrix rich, black inhomogeneous lignite & 66.93 & 8.37 & 17.93 & 3.98 & 2.79 & 5.41 \\
\hline 8 & & V4 & $\begin{array}{l}\text { Unstratified, matrix rich, brown inhomogeneous } \\
\text { lignite with presence of sulphur }\end{array}$ & 60.88 & 16.57 & 8.58 & 10.78 & 3.19 & 4.63 \\
\hline 9 & & V3 & Stratified, matrix rich, brown inhomogeneous lignite & 75.40 & 6.94 & 6.35 & 7.54 & 3.77 & 4.48 \\
\hline 10 & & $\mathrm{~V} 2$ & $\begin{array}{l}\text { Unstratified, matrix rich, brown inhomogeneous } \\
\text { lignite with presence of sulphur and resin patches }\end{array}$ & 58 & 16.00 & 17.20 & 6.0 & 2.8 & 4.61 \\
\hline 11 & & V1 & Stratified, matrix rich, brown inhomogeneous lignite & 82.07 & 8.57 & 2.59 & 3.98 & 2.79 & 4.50 \\
\hline 12 & & Mean & & 69.33 & 10.84 & 9.92 & 6.90 & 3.01 & 4.71 \\
\hline 13 & \multirow{7}{*}{$\begin{array}{l}\text { Vastan lower } \\
\text { lignite seam }\end{array}$} & VL6 & Unstratified, matrix rich, black inhomogeneous lignite. & 75.55 & 7.55 & 2.39 & 7.16 & 7.36 & 11.92 \\
\hline 14 & & VL5 & Stratified, matrix rich, brown inhomogeneous lignite. & 78.17 & 6.94 & 2.58 & 5.56 & 6.75 & 5.76 \\
\hline 15 & & VL4 & $\begin{array}{l}\text { Unstratified, matrix rich, brown inhomogeneous } \\
\text { lignite }\end{array}$ & 78.29 & 11.95 & 2.99 & 5.58 & 1.20 & 6.57 \\
\hline 16 & & VL3 & $\begin{array}{l}\text { Unstratified, matrix rich, brown inhomogeneous } \\
\text { lignite }\end{array}$ & 74.95 & 12.52 & 5.57 & 5.57 & 1.39 & 6.75 \\
\hline 17 & & VL2 & $\begin{array}{l}\text { Unstratified, matrix rich, brown inhomogeneous } \\
\text { lignite }\end{array}$ & 83.07 & 7.17 & 1 & 7.37 & 1.39 & 10.95 \\
\hline 18 & & VL1 & $\begin{array}{l}\text { Unstratified, matrix rich, brown inhomogeneous } \\
\text { lignite }\end{array}$ & 72.06 & 8.18 & 4.59 & 6.59 & 8.58 & 17.52 \\
\hline 19 & & Mean & & 77.01 & 9.06 & 3.18 & 6.30 & 4.44 & 9.91 \\
\hline
\end{tabular}
erally unstratified, matrix rich and inhomogeneous in nature as per ICCP (1993). One xylite rich band of 8-10 cm was observed in Rajpardi seam. Dominantly, the bands

Table 4 Megascopic characteristics of Vastan Lignite Seams along with their petrographic composition and ash yield (after Singh et al. 2016a)

Humi-huminite, lipt-liptinite, inert-inertinite 
Table 5 Megascopic characteristics of Rajpardi Lignite Seam along with its petrographic composition and ash yield (after Singh et al. 2016a)

\begin{tabular}{|c|c|c|c|c|c|c|c|c|c|}
\hline \multirow[t]{2}{*}{$\begin{array}{l}\text { S. } \\
\text { no. }\end{array}$} & & \multirow[t]{2}{*}{$\begin{array}{l}\text { Sample } \\
\text { no. }\end{array}$} & \multirow[t]{2}{*}{ Megascopic characteristics } & \multirow[t]{2}{*}{$\begin{array}{l}\text { Humi } \\
(\operatorname{vol} \%)\end{array}$} & \multirow[t]{2}{*}{$\begin{array}{l}\text { Lipt } \\
(\text { vol\%) }\end{array}$} & \multirow[t]{2}{*}{$\begin{array}{l}\text { Inert } \\
(\text { vol\%) }\end{array}$} & \multicolumn{2}{|c|}{$\begin{array}{l}\text { Mineral } \\
\text { matter }(\operatorname{vol} \%)\end{array}$} & \multirow{2}{*}{$\begin{array}{l}\text { Ash } \\
\text { yield } \\
\text { (wt\%) }\end{array}$} \\
\hline & & & & & & & Pyrite & Other & \\
\hline 1 & \multirow{11}{*}{$\begin{array}{c}\text { Rajpardi } \\
\text { lignite } \\
\text { seam }\end{array}$} & $\mathrm{R} 10$ & $\begin{array}{l}\text { Unstratified, matrix rich, brown inhomogeneous lignite } \\
\text { with presence of sulphur with resin patches }\end{array}$ & 68.71 & 11.88 & 9.31 & 7.92 & 2.18 & 7.99 \\
\hline 2 & & R9 & Unstratified, matrix rich, brown inhomogeneous lignite & 80.04 & 8.70 & 2.77 & 4.94 & 3.56 & 7.47 \\
\hline 3 & & $\mathrm{R} 8$ & $\begin{array}{l}\text { Unstratified, matrix rich, brown inhomogeneous lignite } \\
\text { with presence of sulphur and resin patches }\end{array}$ & 71.29 & 15.45 & 6.14 & 5.54 & 1.58 & 5.23 \\
\hline 4 & & $\mathrm{R} 7$ & $\begin{array}{l}\text { Stratified, matrix rich, brown inhomogeneous lignite } \\
\text { with presence of sulphur and resin patches }\end{array}$ & 76.39 & 12.30 & 4.37 & 5.95 & 0.99 & 5.28 \\
\hline 5 & & R6 & $\begin{array}{l}\text { Unstratified, matrix rich, brown inhomogeneous lignite } \\
\text { with presence of sulphur and resin patches }\end{array}$ & 70.78 & 16.30 & 5.57 & 5.96 & 1.39 & 7.99 \\
\hline 6 & & R5 & $\begin{array}{l}\text { Stratified, xylite rich, brown inhomogeneous lignite } \\
\text { with presence of sulphur }\end{array}$ & 71.09 & 16.24 & 3.17 & 5.94 & 3.56 & 7.83 \\
\hline 7 & & $\mathrm{R} 4$ & $\begin{array}{l}\text { Stratified, matrix rich, brown inhomogeneous lignite } \\
\text { with presence of sulphur and resin patches }\end{array}$ & 67.86 & 11.58 & 5.79 & 9.38 & 5.39 & 13.38 \\
\hline 8 & & R3 & Stratified, matrix rich, brown inhomogeneous lignite. & 76.10 & 10.16 & 5.58 & 4.58 & 3.59 & 6.53 \\
\hline 9 & & $\mathrm{R} 2$ & Stratified, matrix rich, brown inhomogeneous lignite. & 70.44 & 11.31 & 3.37 & 13.10 & 1.79 & 7.82 \\
\hline 10 & & $\mathrm{R} 1$ & $\begin{array}{l}\text { Stratified, matrix rich, black inhomogeneous lignite with } \\
\text { presence of sulphur }\end{array}$ & 73.21 & 9.92 & 8.73 & 4.17 & 3.97 & 4.53 \\
\hline 11 & & Mean & & 72.59 & 12.38 & 5.48 & 6.75 & 2.80 & 7.41 \\
\hline
\end{tabular}

Humi-huminite, lipt-liptinite, inert-inertinite

were of brown colour and the details are discussed by Singh et al. (2016a). Megascopic characteristics of the lignite seams of Cambay basin along with their petrographic composition (maceral groups), mineral matter (pyrite and other minerals) and ash yield are provided in Tables 4, 5 and 6. Pyrite and resin patches could be seen in most of the lithotype bands. Though pyrite is the main mineral present in most of the analysed samples but there is no definite pattern of variation from bottom to the top of lignite seams. Litho column showing various rock units in Cambay Basin along with lignite seam profiles at Vastan, Tadkeshwar and Rajpardi is shown in Fig. 2 while the vertical variation of petrographic components is shown in Fig. 3.

\subsection{Petrography}

The quantitative distribution of individual macerals in the Cambay lignites is provided in Tables 7, 8 and 9. In these lignites, huminite is the dominant maceral group which ranges from $59.3 \%$ to $77.0 \%$ with a mean of $68.7 \%$ (71.6\%-86.3\%, mean $77.92 \%$ on mmf basis) and comprises mainly of detrohuminite followed by telo-huminite and gelo-huminite respectively. Liptinite group is second in dominance and varies from $10.8 \%$ to $16.9 \%$, mean $13.3 \%$ $(10.1 \%-19.3 \%$, mean $14.8 \%$ on mmf basis) and constitutes mainly of sporinite, resinite, liptodetrinite while other macerals of this group occur in small concentration.
Inertinite, which ranges from $5.1 \%$ to $9.9 \%$ (mean $7.9 \%$ ) (3.6\%-11.0\%, mean $7.4 \%$ on mmf basis), is contributed chiefly by funginite, inertodetrinite and fusinite whereas other macerals of this group occur in very low concentration. Mineral matter ranges from $9.0 \%$ to $20.0 \%$, mean $11.8 \%$. There is no definite trend of variation of these petrographic constituents from bottom to top of the lignite seams.

\subsubsection{Vastan lignite}

Maceral composition and mineral matter content in Vastan lignites are furnished in Table 7. Vastan upper lignite seam has a dominance of huminite which varies from $58.0 \%$ to $82.1 \%$, mean $69.3 \%$ (63.6\%-88.0\%, mean $77.0 \%$ on mmf basis). Liptinite is second in dominance and varies from $6.9 \%$ to $16.6 \%$, mean $10.8 \%$ (7.8\%-19.3\%, mean $12.1 \%$ on mmf basis) followed by inertinite which varies from $1.8 \%$ to $17.9 \%$, mean $9.9 \%(2.0 \%-19.2 \%$, mean $11.0 \%$ on mmf basis). The mineral matter content ranges from $6.6 \%$ to $14.0 \%$, mean $9.9 \%$. Similarly, in Vastan lower lignite seam, huminite varies from $72.1 \%$ to $83.1 \%$, mean $77.0 \%$ (80.6\%-91.0\%, mean $86.3 \%$ on $\mathrm{mmf}$ basis), liptinite varies from $6.9 \%$ to $12.5 \%$, mean $9.1 \%(7.9 \%-13.5 \%$, mean $10.1 \%$ on mmf basis), and inertinite varies from $1.0 \%$ to $5.6 \%$, mean $3.2 \%$ (1.1\%-6.0\%, mean 3.6\% on mmf basis). The mineral matter content varies from $6.8 \%$ to $15.2 \%$, mean $10.7 \%$. 
Table 6 Megascopic characteristics of Tadkeshwar Lignite Seams along with their petrographic composition and ash yield (after Singh et al. 2016a)

\begin{tabular}{|c|c|c|c|c|c|c|c|c|c|}
\hline \multirow[t]{2}{*}{$\begin{array}{l}\text { S. } \\
\text { no. }\end{array}$} & & \multirow[t]{2}{*}{$\begin{array}{l}\text { Sample } \\
\text { no. }\end{array}$} & \multirow[t]{2}{*}{ Megascopic characteristics } & \multirow[t]{2}{*}{$\begin{array}{l}\text { Humi } \\
(\text { vol\%) }\end{array}$} & \multirow[t]{2}{*}{$\begin{array}{l}\text { Lipt } \\
(\text { vol\%) }\end{array}$} & \multirow[t]{2}{*}{$\begin{array}{l}\text { Inert } \\
(\text { vol } \%)\end{array}$} & \multicolumn{2}{|c|}{$\begin{array}{l}\text { Mineral } \\
\text { matter }(\text { vol\%) }\end{array}$} & \multirow{2}{*}{$\begin{array}{l}\text { Ash } \\
\text { yoeld } \\
\text { (wt\%) }\end{array}$} \\
\hline & & & & & & & Pyrite & Other & \\
\hline 1 & \multirow{11}{*}{$\begin{array}{l}\text { Tadkeshwar } \\
\text { upper lignite } \\
\text { seam }\end{array}$} & T 10 & $\begin{array}{l}\text { Unstratified, matrix rich, brown inhomogeneous } \\
\text { lignite with presence of sulphur and resin patches }\end{array}$ & 65.67 & 24.40 & 1.39 & 2.78 & 5.75 & 7.68 \\
\hline 2 & & Т 9 & $\begin{array}{l}\text { Unstratified, matrix rich, brown inhomogeneous } \\
\text { lignite with presence of sulphur and resin patches }\end{array}$ & 58.38 & 23.47 & 10.65 & 2.96 & 4.54 & 6.83 \\
\hline 3 & & T 8 & $\begin{array}{l}\text { Unstratified, matrix rich, brown inhomogeneous } \\
\text { lignite }\end{array}$ & 75.90 & 10.16 & 6.18 & 3.39 & 4.38 & 6.08 \\
\hline 4 & & T 7 & $\begin{array}{l}\text { Unstratified, matrix rich, black inhomogeneous } \\
\text { lignite with presence of sulphur and resin patches }\end{array}$ & 55.40 & 19.80 & 14 & 5.2 & 5.60 & 9.53 \\
\hline 5 & & T 6 & $\begin{array}{l}\text { Unstratified, matrix rich, brown inhomogeneous } \\
\text { lignite }\end{array}$ & 64.48 & 14.88 & 13.29 & 3.17 & 4.17 & 5.80 \\
\hline 6 & & T 5 & $\begin{array}{l}\text { Unstratified, matrix rich, brown inhomogeneous } \\
\text { lignite with presence of sulphur }\end{array}$ & 58.50 & 19.37 & 14.23 & 3.36 & 4.55 & 5.19 \\
\hline 7 & & T 4 & $\begin{array}{l}\text { Stratified, matrix rich, brown inhomogeneous lignite } \\
\text { with presence of sulphur }\end{array}$ & 54.74 & 18.18 & 14.82 & 10.47 & 1.78 & 5.16 \\
\hline 8 & & T 3 & $\begin{array}{l}\text { Unstratified, matrix rich, brown inhomogeneous } \\
\text { lignite with presence of sulphur and resin patches }\end{array}$ & 72.85 & 8.38 & 5.99 & 3.99 & 8.78 & 4.96 \\
\hline 9 & & T 2 & $\begin{array}{l}\text { Unstratified, matrix rich, brown inhomogeneous } \\
\text { lignite with presence of sulphur }\end{array}$ & 69.84 & 18.25 & 4.56 & 1.79 & 5.56 & 5.64 \\
\hline 10 & & T 1 & $\begin{array}{l}\text { Stratified, matrix rich, brown inhomogeneous lignite } \\
\text { with presence of sulphur }\end{array}$ & 75.89 & 12.06 & 3.95 & 2.96 & 5.14 & 7.19 \\
\hline 11 & & Mean & & 65.17 & 16.90 & 8.91 & 4.01 & 5.02 & 6.41 \\
\hline 12 & \multirow{7}{*}{$\begin{array}{l}\text { Tadkeshwar } \\
\text { lower lignite } \\
\text { seam }\end{array}$} & TL7 & $\begin{array}{l}\text { Stratified, matrix rich, brown inhomogeneous lignite } \\
\text { with presence of sulphur }\end{array}$ & 66.47 & 14.09 & 1.39 & 12.10 & 5.95 & 9.55 \\
\hline 13 & & TL6 & $\begin{array}{l}\text { Unstratified, matrix rich, brown inhomogeneous } \\
\text { lignite }\end{array}$ & 56.83 & 22.57 & 4.75 & 12.48 & 3.37 & 10.91 \\
\hline 14 & & TL5 & $\begin{array}{l}\text { Stratified, matrix rich, brown inhomogeneous lignite } \\
\text { with presence of sulphur }\end{array}$ & 61.51 & 21.23 & 4.17 & 8.33 & 4.76 & 9.83 \\
\hline 15 & & TL4 & $\begin{array}{l}\text { Untratified, matrix rich, brown inhomogeneous } \\
\text { lignite with presence of sulphur }\end{array}$ & 58.33 & 10.71 & 3.97 & 19.05 & 7.94 & 10.06 \\
\hline 16 & & TL3 & $\begin{array}{l}\text { Stratified, matrix rich, brown inhomogeneous lignite } \\
\text { with presence of sulphur }\end{array}$ & 57.46 & 6.76 & 4.97 & 29.03 & 1.79 & 23.28 \\
\hline 17 & & TL2 & $\begin{array}{l}\text { Unstratified, matrix rich, brown inhomogeneous } \\
\text { lignite with presence of sulphur and resin patches }\end{array}$ & 51.98 & 17.86 & 7.74 & 19.44 & 2.98 & 9.70 \\
\hline 18 & & TL1 & $\begin{array}{l}\text { Stratified, matrix rich, brown inhomogeneous lignite } \\
\text { with presence of sulphur and resin patches }\end{array}$ & 61.88 & 16.97 & 8.58 & 7.98 & 4.59 & 10.65 \\
\hline
\end{tabular}

Humi-huminite, lipt-liptinite, inert-inertinite

\subsubsection{Tadkeshwar lignite}

Maceral composition and mineral matter content in Tadkeshwar lignites are furnished in Table 8. In Tadkeshwar upper lignite seam, huminite is the dominant maceral group and varies from $54.7 \%$ to $75.9 \%$, mean $65.2 \%$ (62.1\%$83.5 \%$, mean $71.6 \%$ on mmf basis). Liptinite varies from $8.4 \%$ to $24.4 \%$, mean $16.9 \%$ (9.8\%-26.8\%, mean $19.3 \%$ on mmf basis). Inertinite varies from $1.4 \%$ to $14.8 \%$, mean $8.9 \%(1.5 \%-16.9 \%$, mean $9.8 \%$ on mmf basis). Mineral matter varies from $7.3 \%$ to $12.8 \%$, mean $9.0 \%$. In Tadkeshwar lower lignite seam also huminite is the dominant maceral group and ranges from $52.0 \%$ to $66.5 \%$, mean
59.3\% (67.0\%-83.0\%, mean $74.4 \%$ on mmf basis). Liptinite is second in abundance and varies from $6.8 \%$ to $22.6 \%$, mean $15.7 \%$ (9.8\%-26.8\%, mean $19.3 \%$ on mmf basis) followed by inertinite which varies from $1.4 \%$ to $8.6 \%$, mean $5.1 \%(1.7 \%-10.0 \%$, mean $6.4 \%$ on $\mathrm{mmf}$ basis). Mineral matter ranges from $12.6 \%$ to $30.8 \%$, mean $20.0 \%$.

\subsubsection{Rajpardi lignite}

Maceral composition and mineral matter content in Rajpardi lignites are furnished in Table 9. In this lignite seam, huminite dominates and ranges from $67.9 \%$ to $80.0 \%$, 


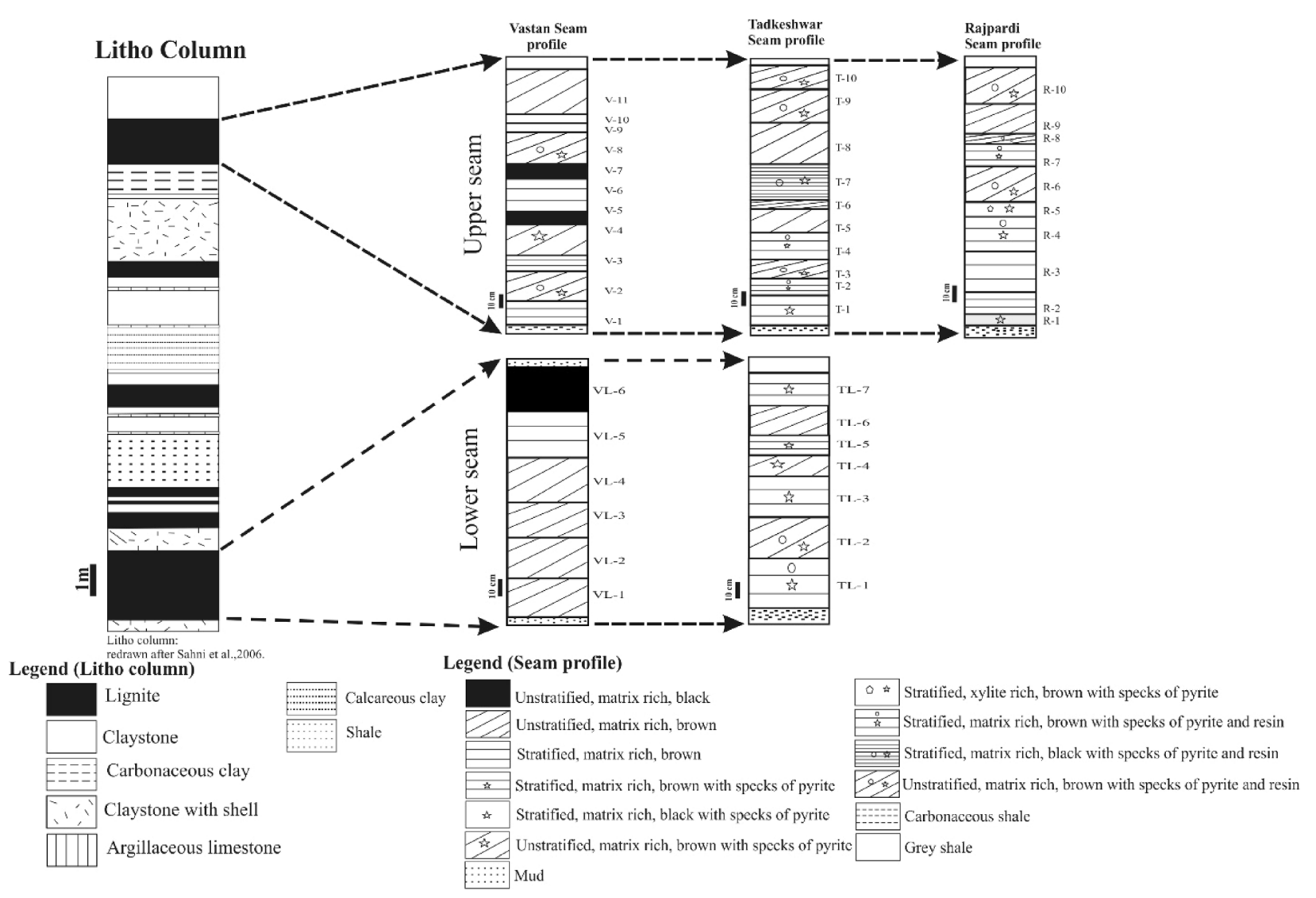

Fig. 2 Litho column showing various rock units in Cambay Basin (after Sahni et al. 2006) along with lignite seam profiles at Tadkeshwar, Vastan and Rajpardi

mean $72.6 \%$ (76.4\%-87.5\%, mean $80.3 \%$ on mmf basis). Liptinite is next in dominance and varies from $8.7 \%$ to $16.3 \%$, mean $12.4 \%$ (9.5\%-17.9\%, mean $13.7 \%$ on mmf basis) followed by inertinite which varies from $2.8 \%$ to $9.3 \%$, mean $5.5 \%$ (3.0\%-10.4\%, mean $6.1 \%$ on mmf basis). The mineral matter varies from $6.9 \%$ to $14.9 \%$, mean $9.5 \%$. The characteristic photomicrographs in the lignites of Cambay basin is shown in Fig. 4.

The huminite reflectance measurement of the lignites of Cambay Basin shows that Ro min ranges from $0.07 \%$ to $0.25 \%$ (average $0.15 \%$ ), Ro max from $0.45 \%$ to $0.46 \%$ (average $0.45 \%$ ), and Ro mean from $0.27 \%$ to $0.34 \%$ (average $0.31 \%$ ). The standard deviation varies from 0.04 to 0.08 (average 0.06). Details of the reflectance values of individual lignite samples of various seams are furnished in Table 10.

\subsection{Paleomires}

The qualitative and quantitative petrographic data has been used to discuss the evolutionary history of the lignites of Cambay of Gujarat in this section. For this purpose, the data has been generated on the lignite samples collected from all the working mines of the Cambay (Vastan, Rajpardi and Tadkeshwar mines). The generated data is useful in understanding the coal facies, nature of flora, and depositional controls on the development of peat.

It is important to understand the variations in the petrographic constituents of Gujarat lignites along the lignite seam profiles, from bottom to top, in order to know their evolutionary history. In the Cambay basin, brown bands are more prevalent and are mostly unstratified and contain high matrix while only few black, thin bands (V-5, VL-6, R-1, and T-7; Tables 4, 5, 6; Fig. 2) are seen. The black bands in these lignites, are relatively more strongly gelified compared to the brownish bands. More gelification could be caused as a result of anaerobic processes (Iordanidis and Georgakopoulos 2003). Various shades of darkness could also result due to different degrees of plant decomposition (Hagemann and Wolf (1987). The black bands have very high detro-huminite content with little bit less amount of telo-huminite content. Since macerals directly relate to the plants and environment, they provide useful guide to characterize the paleomire. Certain macerals are indicative of paleo-depositional environment, through their presence or absence, (Teichmüller 1989). The characteristics 


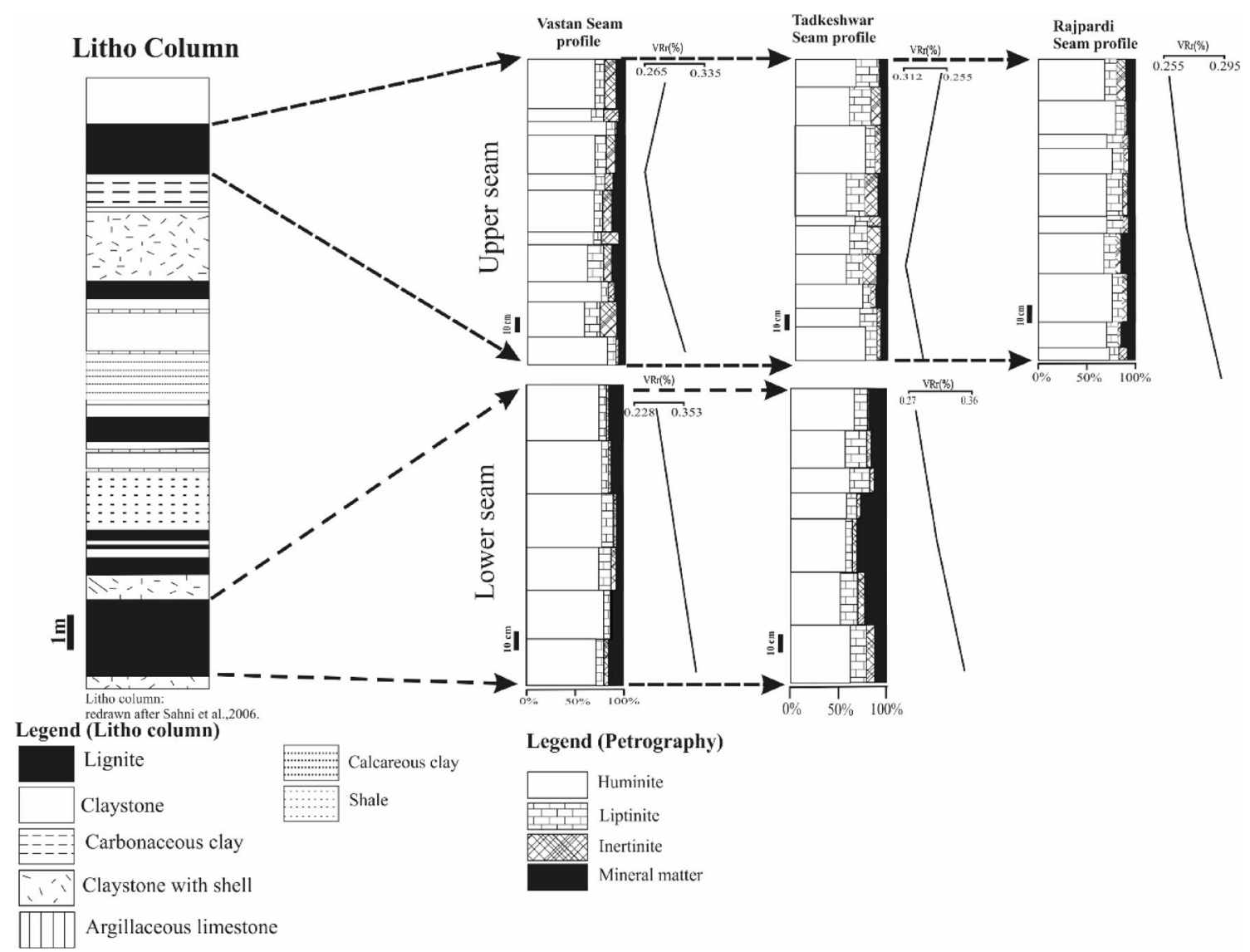

Fig. 3 Litho column showing various rock units in Cambay Basin (after Sahni et al. 2006) along with vertical variation of petrographic constituents in the lignite seams at Tadkeshwar, Vastan and Rajpardi area

imparted to coal differ with variation in the peat forming plant communities, nutrient supply, temperature, $\mathrm{pH}$, bacterial activity, redox potential and types of deposition (Teichmüller et al. 1998a, b, c; Lin and Tian 2011). Increase in the clastic mineral matter relates to the surface inundation in the basin (Singh and Singh 1996). Petrography based facies models have been used to discuss the evolutionary history of the paleomires of the Cambay basin. Using petrological tools a number of researchers have successfully performed paleoecological reconstructions and contributions have been made by Cohen and Spackman (1972), Styan and Bustin (1983), Cohen et al. (1987), Calder et al. (1991), Grady et al. (1993), Hawke et al. (1996), Singh and Singh (1996), Shearer and Clarkson (1998), Sun et al. (1998), Dai et al. (2007), Jasper et al. (2010), Singh et al. (2010a, b), Deng and Sun (2011), and Singh et al. (2012a, b, c, d). Detro-huminite is throughout high in the lignites of Cambay basin wherein densinite is more consistent. With decrease in the densinite content, there is concomitant increase in the respective attrinite content. Detro-huminite is normally generated in relatively aerobic condition (Teichmüller et al. 1998b). Moreover, the activities of physical breakdown of plant to particulate matrix are observed at the margin of the peat beds (Kuder et al. 1998). To characterize the paleomires of the Australian Permian coals, Diessel (1986) introduced two indices, gelification index (GI) and tissue preservation index (TPI). Less humified structured and strongly humified unstructured tissue derived macerals indicate the degree of humification and the vegetation type (Diessel 1992). Accordingly, a high TPI value suggests a high subsidence rate of basin and dominance of wood derived tissues, and a low TPI suggests a low subsidence rate with high humification. The degree of gelification of huminite macerals is revealed by GI which distinguishes between gelified and ungelified macerals. For gelification to take place a continuous presence of water is necessary and fluctuation in water table is likely to affect the degree of gelification. However, these indices should be calculated and used carefully. Researchers like Calder (1993) and Collinson and Scott (1987) believe that the palynological and paleobotanical data provide higher precision in the determination of paleoenvironment. Several researchers have objected the usage of such indices for Tertiary or low 


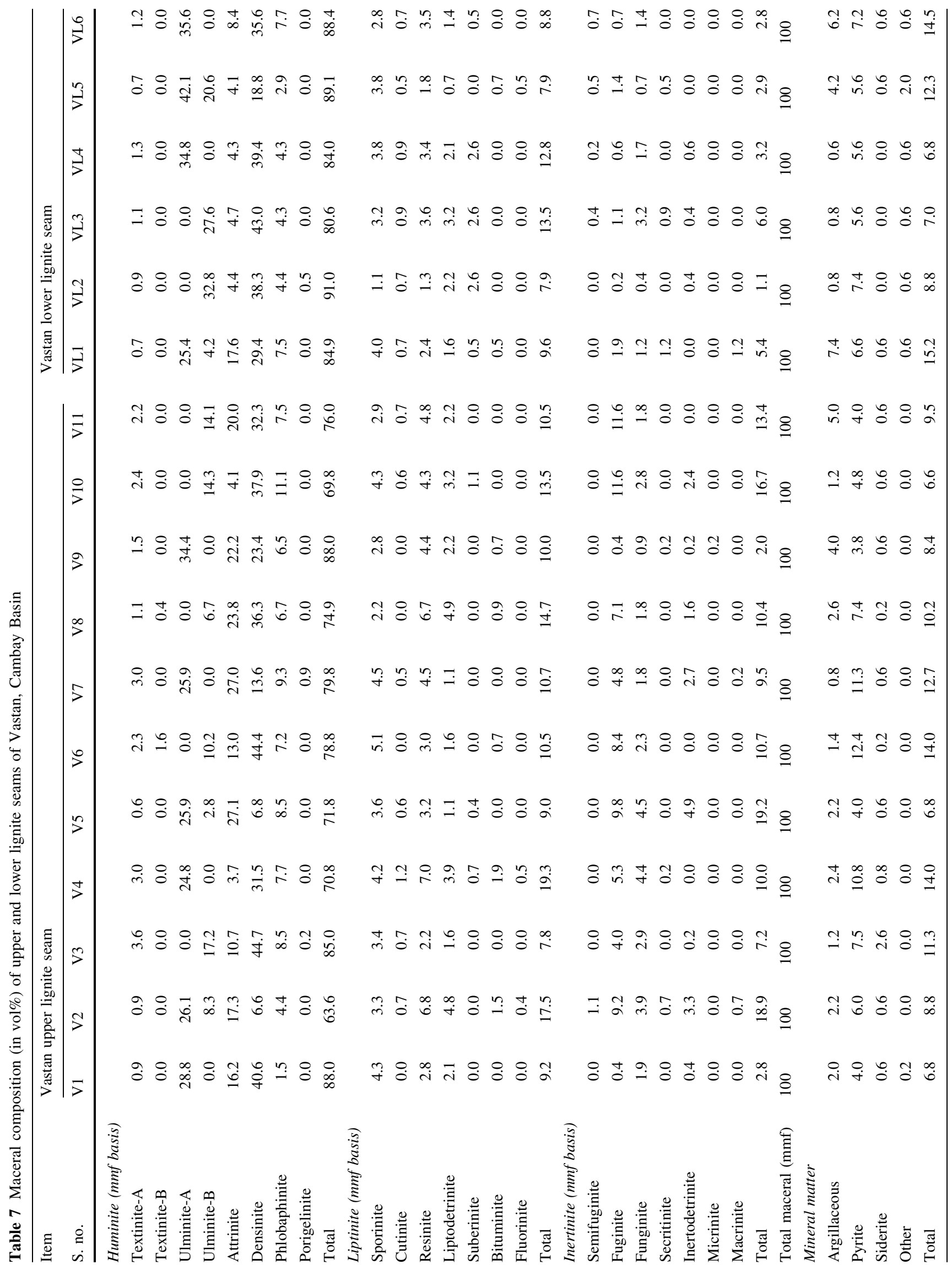




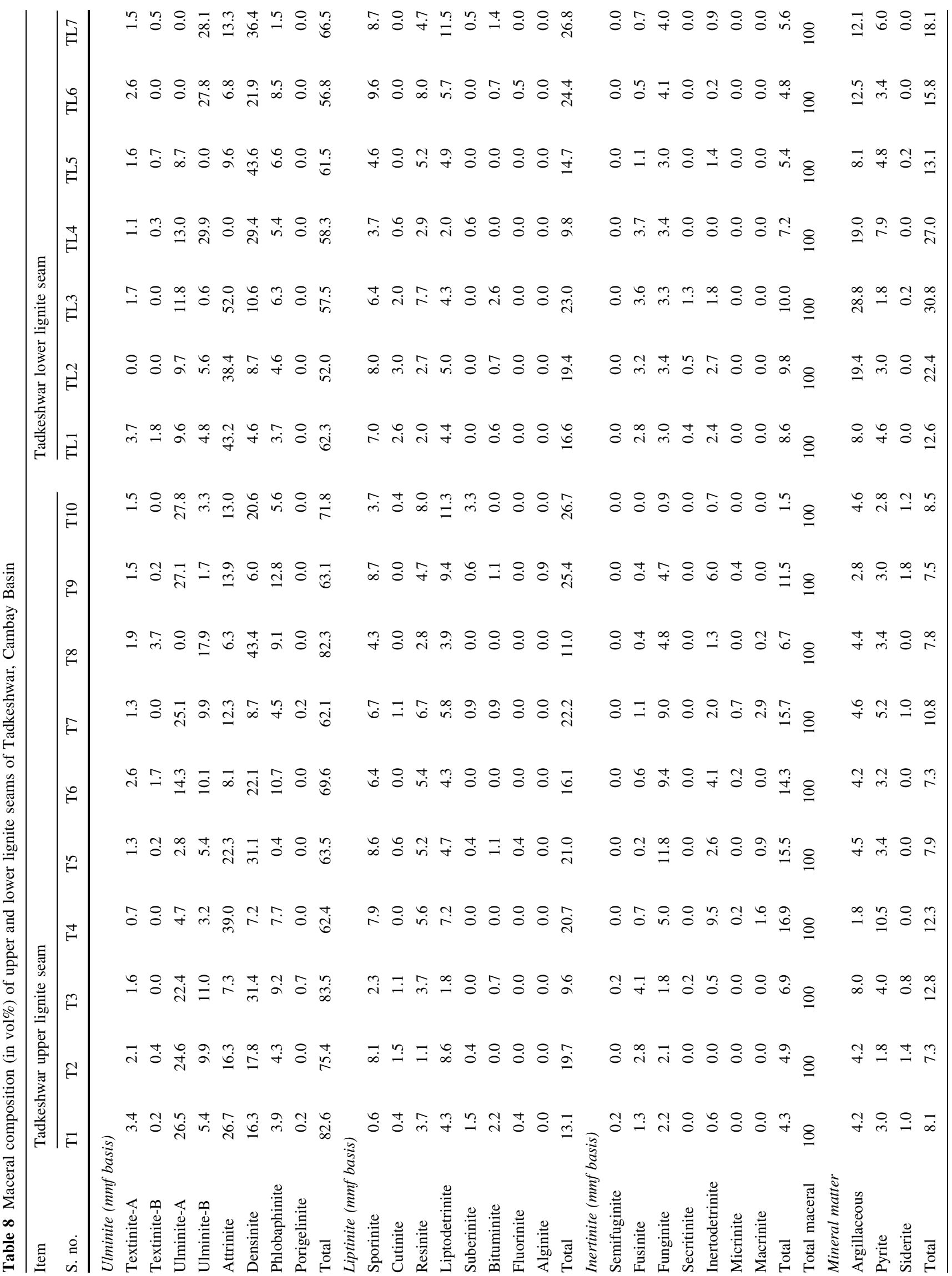


Table 9 Maceral composition (in vol\%) of upper and lower lignite seams of Rajpardi, Cambay Basin

\begin{tabular}{|c|c|c|c|c|c|c|c|c|c|c|}
\hline S. no. & $\mathrm{R} 1$ & $\mathrm{R} 2$ & R3 & $\mathrm{R} 4$ & R5 & R6 & $\mathrm{R} 7$ & $\mathrm{R} 8$ & R9 & $\mathrm{R} 10$ \\
\hline \multicolumn{11}{|c|}{ Huminite (mmf basis) } \\
\hline Textinite-A & 1.7 & 0.7 & 0.9 & 1.4 & 2.6 & 1.3 & 0.4 & 1.7 & 3.9 & 0.0 \\
\hline Textinite-B & 0.0 & 0.2 & 0.0 & 0.5 & 1.3 & 0.6 & 0.0 & 1.1 & 1.9 & 0.0 \\
\hline Ulminite-A & 21.6 & 12.1 & 24.1 & 8.7 & 12.3 & 3.9 & 16.2 & 16.2 & 14.3 & 12.3 \\
\hline Ulminite-B & 13.4 & 24.5 & 13.7 & 3.3 & 3.1 & 8.6 & 7.2 & 11.1 & 23.8 & 1.1 \\
\hline Attrinite & 10.4 & 12.6 & 12.4 & 28.6 & 16.4 & 27.5 & 28.1 & 17.7 & 11.4 & 42.7 \\
\hline Densinite & 30.2 & 29.6 & 26.9 & 32.8 & 35.4 & 30.0 & 25.2 & 22.6 & 28.9 & 19.4 \\
\hline Phlobaphinite & 2.4 & 2.8 & 4.1 & 4.4 & 7.4 & 4.5 & 4.9 & 6.2 & 2.2 & 0.9 \\
\hline Levigelinite & 0.0 & 0.2 & 0.0 & 0.0 & 0.0 & 0.0 & 0.0 & 0.2 & 0.0 & 0.0 \\
\hline Porigelinite & 0.0 & 0.0 & 0.9 & 0.0 & 0.0 & 0.0 & 0.0 & 0.0 & 1.1 & 0.0 \\
\hline Total & 79.7 & 82.8 & 82.9 & 79.6 & 78.6 & 76.4 & 82.1 & 76.8 & 87.5 & 76.4 \\
\hline \multicolumn{11}{|c|}{ Liptinite (mmf basis) } \\
\hline Sprinite & 2.6 & 4.2 & 3.9 & 3.5 & 5.5 & 3.9 & 3.6 & 2.6 & 3.2 & 4.0 \\
\hline Cutinite & 0.0 & 0.5 & 0.4 & 0.7 & 2.8 & 1.5 & 1.5 & 0.0 & 0.9 & 1.5 \\
\hline Resinite & 3.9 & 1.6 & 2.8 & 3.5 & 6.6 & 4.1 & 4.3 & 5.3 & 3.2 & 3.7 \\
\hline Liptodetrinite & 3.7 & 6.5 & 3.3 & 4.7 & 2.6 & 4.9 & 2.8 & 5.8 & 2.2 & 2.9 \\
\hline Suberinite & 0.6 & 0.0 & 0.0 & 0.0 & 0.0 & 0.0 & 0.0 & 0.0 & 0.0 & 1.1 \\
\hline Bituminite & 0.0 & 0.0 & 0.7 & 1.2 & 0.0 & 3.2 & 1.1 & 2.6 & 0.0 & 0.0 \\
\hline Fluorinite & 0.0 & 0.5 & 0.0 & 0.0 & 0.0 & 0.0 & 0.0 & 0.4 & 0.0 & 0.0 \\
\hline Alginite & 0.0 & 0.0 & 0.0 & 0.0 & 0.4 & 0.0 & 0.0 & 0.0 & 0.0 & 0.0 \\
\hline Total & 10.8 & 13.3 & 11.1 & 13.6 & 17.9 & 17.6 & 13.2 & 16.6 & 9.5 & 13.2 \\
\hline \multicolumn{11}{|c|}{ Inertinite (mmf basis) } \\
\hline Pyrofusinite & 5.2 & 1.4 & 1.3 & 1.2 & 0.4 & 1.5 & 1.3 & 1.7 & 1.1 & 2.9 \\
\hline Funginite & 2.8 & 1.6 & 3.7 & 2.8 & 2.0 & 3.9 & 2.1 & 3.6 & 1.3 & 5.3 \\
\hline Secretinite & 0.2 & 0.2 & 0.2 & 0.2 & 0.0 & 0.0 & 0.0 & 0.0 & 0.0 & 0.0 \\
\hline Inertodetrinite & 0.9 & 0.5 & 0.4 & 1.9 & 1.1 & 0.6 & 0.4 & 1.3 & 0.4 & 2.2 \\
\hline Micrinite & 0.2 & 0.2 & 0.2 & 0.7 & 0.0 & 0.0 & 0.6 & 0.0 & 0.2 & 0.0 \\
\hline Macrinite & 0.2 & 0.0 & 0.0 & 0.0 & 0.0 & 0.0 & 0.2 & 0.0 & 0.0 & 0.0 \\
\hline Total & 9.5 & 4.0 & 6.1 & 6.8 & 3.5 & 6.0 & 4.7 & 6.6 & 3.0 & 10.4 \\
\hline Total maceral & 100.0 & 100.0 & 100.0 & 100.0 & 100.0 & 100.0 & 100.0 & 100.0 & 100.0 & 100.0 \\
\hline \multicolumn{11}{|l|}{ Mineral matter } \\
\hline Argillaceous & 3.4 & 1.4 & 2.8 & 4.8 & 3.4 & 0.6 & 0.8 & 0.8 & 3.2 & 1.4 \\
\hline Pyrite & 4.2 & 13.1 & 4.6 & 9.4 & 5.9 & 6.0 & 6.0 & 5.5 & 4.9 & 7.9 \\
\hline Siderite & 0.6 & 0.4 & 0.8 & 0.6 & 0.2 & 0.8 & 0.2 & 0.8 & 0.4 & 0.8 \\
\hline Total & 8.1 & 14.9 & 8.2 & 14.8 & 9.5 & 7.4 & 6.9 & 7.1 & 8.5 & 10.1 \\
\hline
\end{tabular}

rank coals (Lambersen et al. 1991; Crosdale 1993; Dehmer 1995; Wust et al. 2001; Scott 2000; Moore and Shearer 2003; Amijaya and Littke 2005). Few researchers have tried a combination of petrographic, organic geochemical and/or isotope data (Bechtel et al. 2002, 2003, 2007a, b, 2008; Mayr et al. 2009; Savard et al. 2012; Singh et al. 2012c) for the reconstruction of paleoenvironment. Kalkreuth et al. (1991), Petersen (1993), and Flores (2002) further modified these indices to make them useful for the low rank coals too. In the present investigation, the indices have been taken from Flores (2002) which is a modified version of Kalkreuth et al. (1991), for brown coals.
The lignites of Cambay basin are characterized by high GI and low TPI values indicating a continuous wet condition in the basin and a relatively slow rate of subsidence during the decay of organic matter. Few sections in Tadkeshwar seam suffered relatively drier spells as revealed by moderately high content of inertinite macerals. This is especially revealed by the occurrence of funginite which normally thrives in the upper oxygenated peatigenic layer and indicates prevalence of oxic conditions. This indicates fluctuation in the water cover in the peat swamp. Hoekel (1989) believes that intensive gelification of plant tissues is a function of acid ground water due to marine influence. 

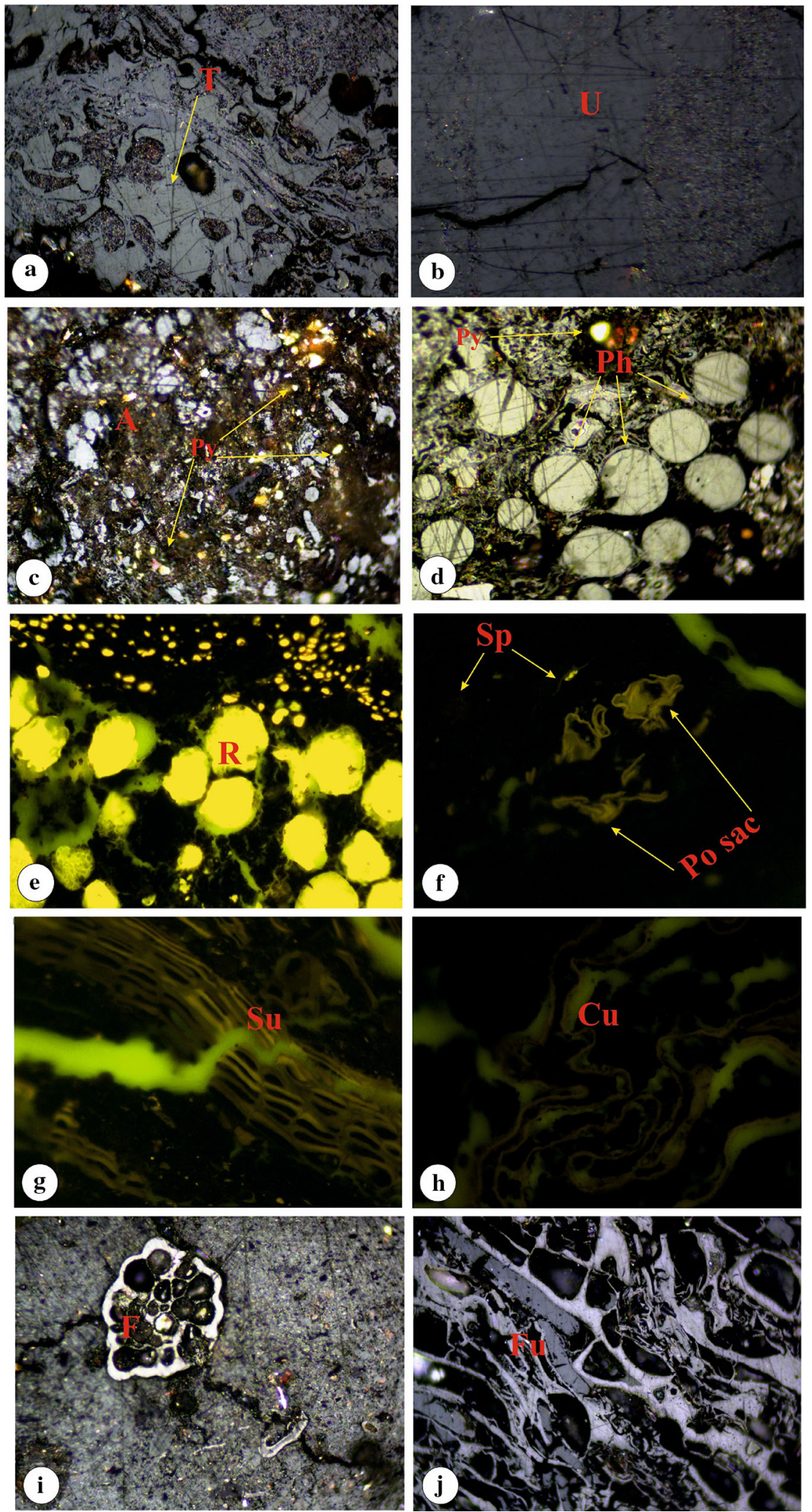

Fig. 4 Characteristic photomicrographs in the lignites of Cambay Basin: a textinite (T); $\mathbf{b}$ ulminite with oxidation cracks; $\mathbf{c}$ attrinite (A) with pyrite grains; $\mathbf{d}$ phlopbaphinite $(\mathrm{Ph})$ with oxidation cracks; $\mathbf{e}$ resinite $(\mathrm{R}) \mathbf{f}$ sporinite $(\mathrm{Sp})$ with pollen $(\mathrm{Po})$ sac; $\mathbf{g}$ suberinite $(\mathrm{Su})$ and cutinite $(\mathrm{Cu})$ observed under uv light; $\mathbf{h}$ megacutinite $(\mathrm{Cu})$ as observed under uv light; $\mathbf{i}$ fungal bodies $(\mathrm{F})$ occurring in densinitic background; $\mathbf{j}$ fusinite band (Fu) and densinite (D) 
Table 10 Results of the reflectance measurements in the lignite seams of Cambay Basin, Gujarat

\begin{tabular}{|c|c|c|c|c|c|c|c|}
\hline Basin & Mines/seams & Sample & Rom value (\%) & Maximum (\%) & Minimum (\%) & Standard deviation & Variance \\
\hline \multirow[t]{22}{*}{ Cambay } & \multirow[t]{9}{*}{ Tadkeshwar } & T10 & 0.33 & 0.46 & 0.1 & 0.06 & 0.0 \\
\hline & & $\mathrm{T} 7$ & 0.32 & 0.41 & 0.21 & 0.05 & 0.0 \\
\hline & & T5 & 0.31 & 0.48 & 0.12 & 0.07 & 0.01 \\
\hline & & $\mathrm{T} 1$ & 0.32 & 0.47 & 0.11 & 0.08 & 0.01 \\
\hline & & Mean & 0.32 & 0.46 & 0.14 & 0.07 & 0.01 \\
\hline & & TL7 & 0.28 & 0.46 & 0.14 & 0.06 & 0.0 \\
\hline & & TL5 & 0.31 & 0.45 & 0.2 & 0.06 & 0.0 \\
\hline & & TL1 & 0.35 & 0.43 & 0.23 & 0.03 & 0.0 \\
\hline & & Mean & 0.31 & 0.45 & 0.19 & 0.05 & 0.0 \\
\hline & \multirow[t]{4}{*}{ Rajpardi } & R10 & 0.26 & 0.47 & 0.08 & 0.1 & 0.01 \\
\hline & & R7 & 0.27 & 0.42 & 0.04 & 0.06 & 0.0 \\
\hline & & $\mathrm{R} 1$ & 0.29 & 0.47 & 0.1 & 0.08 & 0.01 \\
\hline & & Mean & 0.27 & 0.45 & 0.07 & 0.08 & 0.01 \\
\hline & \multirow[t]{9}{*}{ Vastan } & V11 & 0.3 & 0.4 & 0.15 & 0.04 & 0.0 \\
\hline & & V9 & 0.27 & 0.44 & 0.07 & 0.08 & 0.01 \\
\hline & & V5 & 0.29 & 0.49 & 0.03 & 0.08 & 0.01 \\
\hline & & V1 & 0.33 & 0.47 & 0.08 & 0.08 & 0.01 \\
\hline & & Mean & 0.3 & 0.45 & 0.08 & 0.07 & 0.01 \\
\hline & & VL6 & 0.33 & 0.42 & 0.26 & 0.04 & 0.0 \\
\hline & & VL4 & 0.34 & 0.42 & 0.29 & 0.02 & 0.0 \\
\hline & & VL1 & 0.35 & 0.5 & 0.19 & 0.07 & 0.0 \\
\hline & & Mean & 0.34 & 0.45 & 0.25 & 0.04 & 0.0 \\
\hline
\end{tabular}

This could further increase the acidity and lead to gelification and could have been the case with the Cambay lignites. Moreover, detrital vitrinite is formed under limnotelmatic and open marsh environment. A low TPI value $(<0.5)$ and a high GI $(>6)$ is indicative of a topogenous mire while a very high GI value $(>10)$ indicates a permanently flooded condition leading to a pronounced degree of degradation of vegetal matter. Such situations prevailed on several occasions during the formation of seams in Tadkeshwar, Rajpardi and Vastan seams of Cambay Basin (Fig. 5) which is a typical of a limno-telmatic swamp having a low subsidence rate and a slow fall in the ground water table. Moreover, such areas have treeless open marsh and limnic plant communities (Iordanidis and Georgakopoulos 2003). The formation of Vastan lower seam began and continued further under a limno-telmatic environment and during the formation of upper part of this seam, there was a shifting towards telmatic environment for a shorter period as indicated by a sudden increase in the TPI values and again there was a shifting to a limno-telmatic environment. Similarly, the formation of Vastan upper seam also began under limno-telmatic environment; it shifted to telmatic environment for a relatively shorter period, as indicated by its thin band, and then returned to limno-telmatic condition which persisted for most part of the time. However, during the formation of upper part of this seam, there was again a small shift to telmatic environment but soon it returned back to limno-telmatic condition. Similarly, the formation of Tadkeshwar Lower seam as well as Tadkeshwar Upper seam formed under limnotelmatic to telmatic condition while Rajpardi seam evolved under limno-telmatic environment where the values of TPI are $<1$. This is also in concurrence with the study of Jasper et al. (2010). There exists a strong sympathetic correlation between ash content and sulphur content $(r=0.92$ in Rajpardi; $r=0.91$ in Vastan; $r=0.88$ in Tadkeshwar) supporting the above view that clastic sedimentation has increased the tree density and tissue preservation in the Cambay Basin. This is also evident from a low to moderate but positive correlation between TPI and clastic minerals $(r=0.42$ in Tadkeshwar, $r=0.17$ in Vastan, and $r=0.10$ in Rajpardi seams). A similar observation was also noticed in Nagaland coals of north-eastern India (Singh et al. 2012b). However, a low but negative correlation value exists between GI and TPI values $(r=-0.09$ for Tadkeshwar lignite, and $r=-0.02$ for Vastan lignite of Cambay Basin).

Possibility of a eustatic rise of 70-140 $\mathrm{m}$ in the sea level during Early Paleogene period, as compared to the present level, is discussed by Haq et al. (1987). This is indicated by global transgressions during 58.5-52.8 Ma. The signatures are seen in the Late Paleocene-Early Eocene sedimentary 


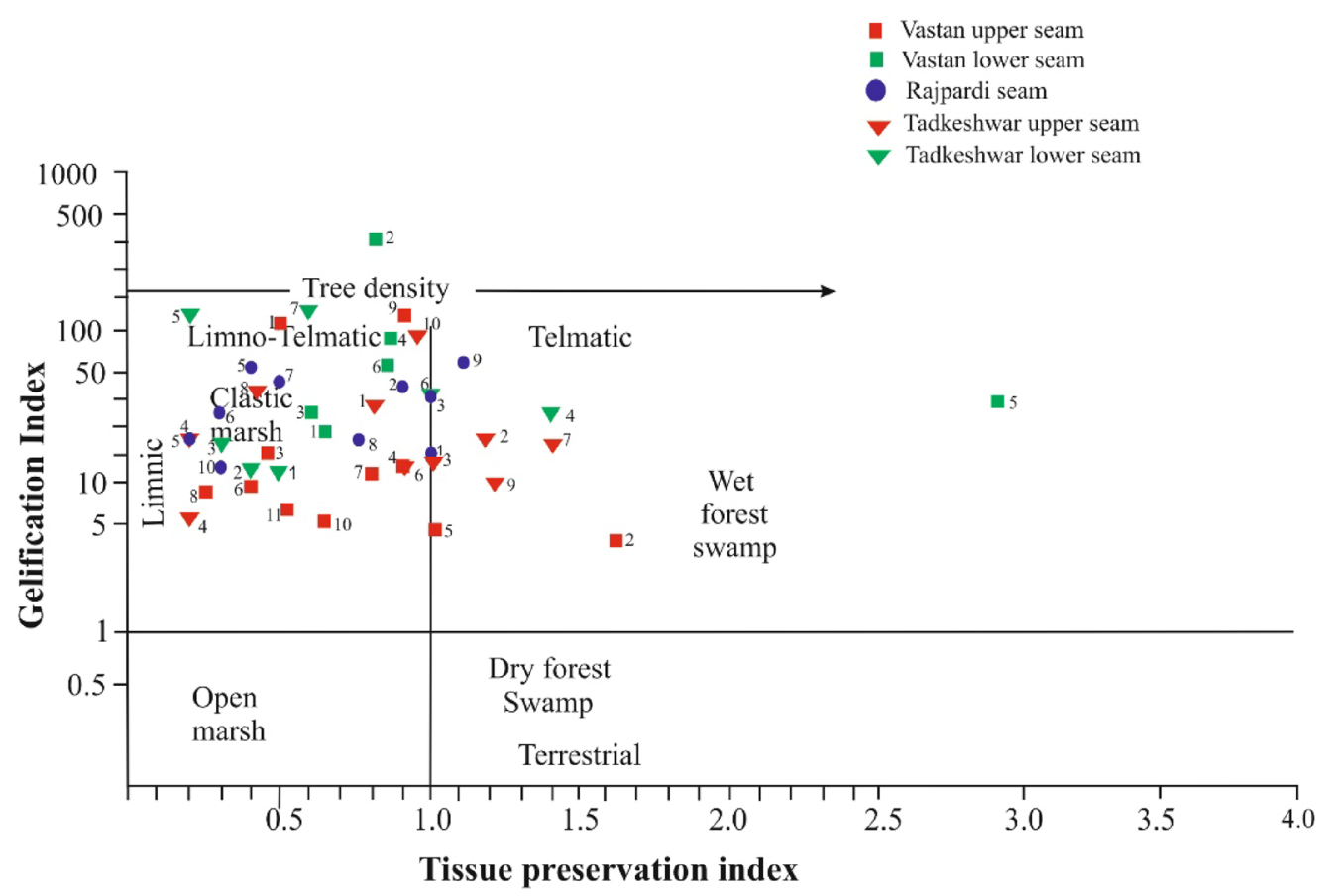

Fig. 5 Coal facies determined from Gelification Index (GI) and the Tissue Preservation Index (TPI) in relation to depositional setting and type of mire for the lignites of Cambay Basin, Gujarat (modified from Diessel 1986)

sequences (Sluijs et al. 2008; Prasad et al. 2013). Hardenbol et al. (1998) have expressed similar views and believed that during 55-52 Ma the eustatic sea-level curve was high and showed a little fluctuation. Owing to the significance of ground water as a parameter controlling the environment of a paleomire, Calder et al. (1991) proposed ground water index (GWI) and vegatation index (VI) for paleoenvironmental reconstruction. Mires generally form in successive variations between ombrotrophic and rheotrophic hydrological conditions. While ombrotrophic to mesotrophic paleoenvironments show usually low $(<1)$ GWI values; rheotrophic hydrological condition is characterized by $>1$ GWI values. Extreme condition of $>5$ values point to drowning of peat. The GWI and VI values of the investigated Cambay basin lignites suggest a mainly rheotrophic paleoenvironment (Fig. 6) though mesotrophic paleoenvironmental condition existed for a very shorter span during the seam formation in few sections. Further, the mire is characterized by the dominance of herbaceous to marginal aquatic vegetation. It is considered that attrinite and densinite are the chief constituents of lignites (Iordanidis and Georgakopoulos 2003) of treeless marshes. Diessel (1992) discusses that a wet forest may also produce a peat having similar petrographic composition as that of marsh peats provided a favourable condition prevails in the basin for microbial destruction. Variation of GI, TPI, GWI and VI values with depth in the lignite seams of Cambay Basin is shown in Fig. 7.
A ternary model proposed by Singh et al. (2012a), initially proposed for understanding the paleomires of the Eocene lignite deposit of Rajpardi, has been used in the present investigation. This model is based on maceral composition as well as clastic mineral content. Since the clastic minerals relate directly to the water cover in the basin, it provides a better understanding related to the fluctuations of the water cover in the basin. The data plots of Cambay lignites on this model (Fig. 8) indicate their origin in wet moor with moderate to high flooding where the tissue preservation was moderate. The results obtained through the petrography-based ternary models compare well with the ones shown by GI, TPI, GWI and VI indices. The presence of framboidal pyrite indicates increasing activity of sulfate-reducing bacteria in the carbonate and sulphate rich waters of the basin at the time of peat formation (Kuder et al. 1998; Teichmüller et al. 1998a). Bacterial activity is the source of energy for such chemical reduction from sulphate to sulfides (Neavel 1966). Under these situations adsorption of iron is seen on clays and pyrite is found adjacent to clay zones (Cabrera et al. 1995). Presence of clay rich layers in the lignites of Cambay basin is confirmed by the $\mathrm{X}$-ray diffraction study showing marine influence in this basin where the pyrite framboids formed through bacterial activity. The petrography based facies models used in the present investigation for the reconstruction of the paeoenvironment of Cambay basin points to a coastal marshy setting for the evolution of these 


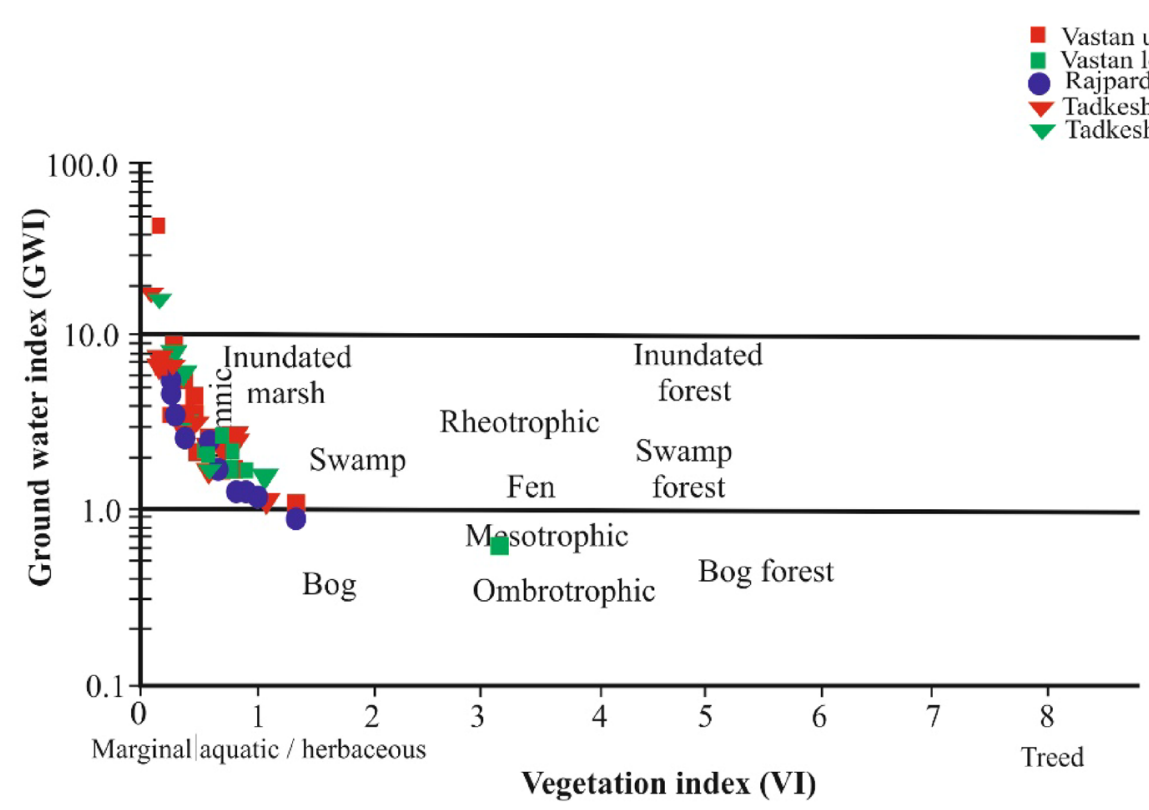

Fig. 6 Plots of ground water influence index (GWI) versus vegetation index (VI) for the lignites of Cambay Basin, Gujarat (after Calder et al. 1991)
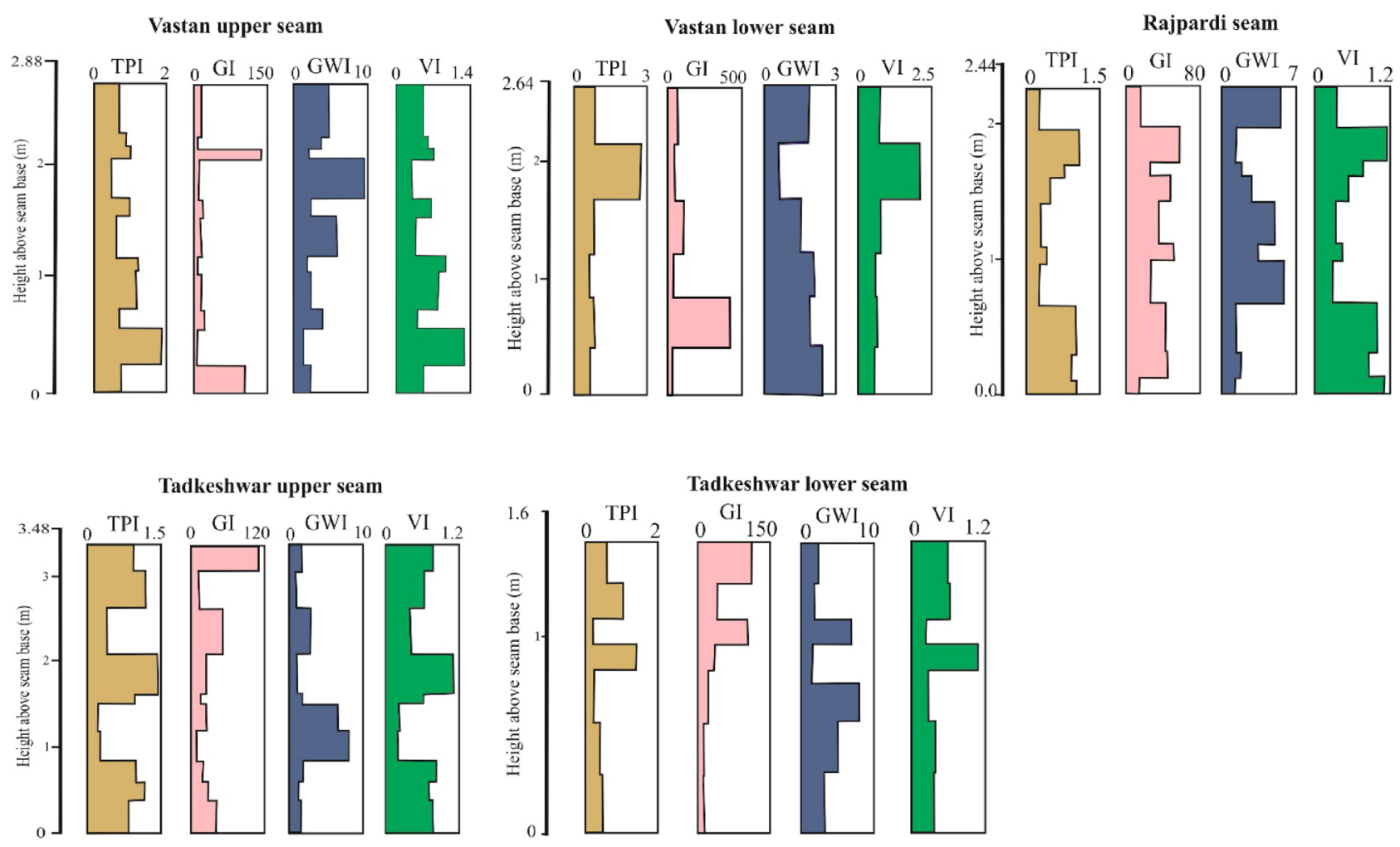

Fig. 7 Vertical variation of GI, TPI, GWI and Vi with depth in the lignites seams of Cambay Basin

lignites. This environmental condition prevailed during transgressive phase, but there were intermittent fluvial activities giving rise to supratidal flood plain as indicated by the presence of associated carbonaceous shales, shales and green shales in the basin. The marshy coal plain to bay model of Prasad et al. (2013) supports the view and also explain the cyclicity of various lithofacies. While discussing the depositional paleoenvironment of Vastan 


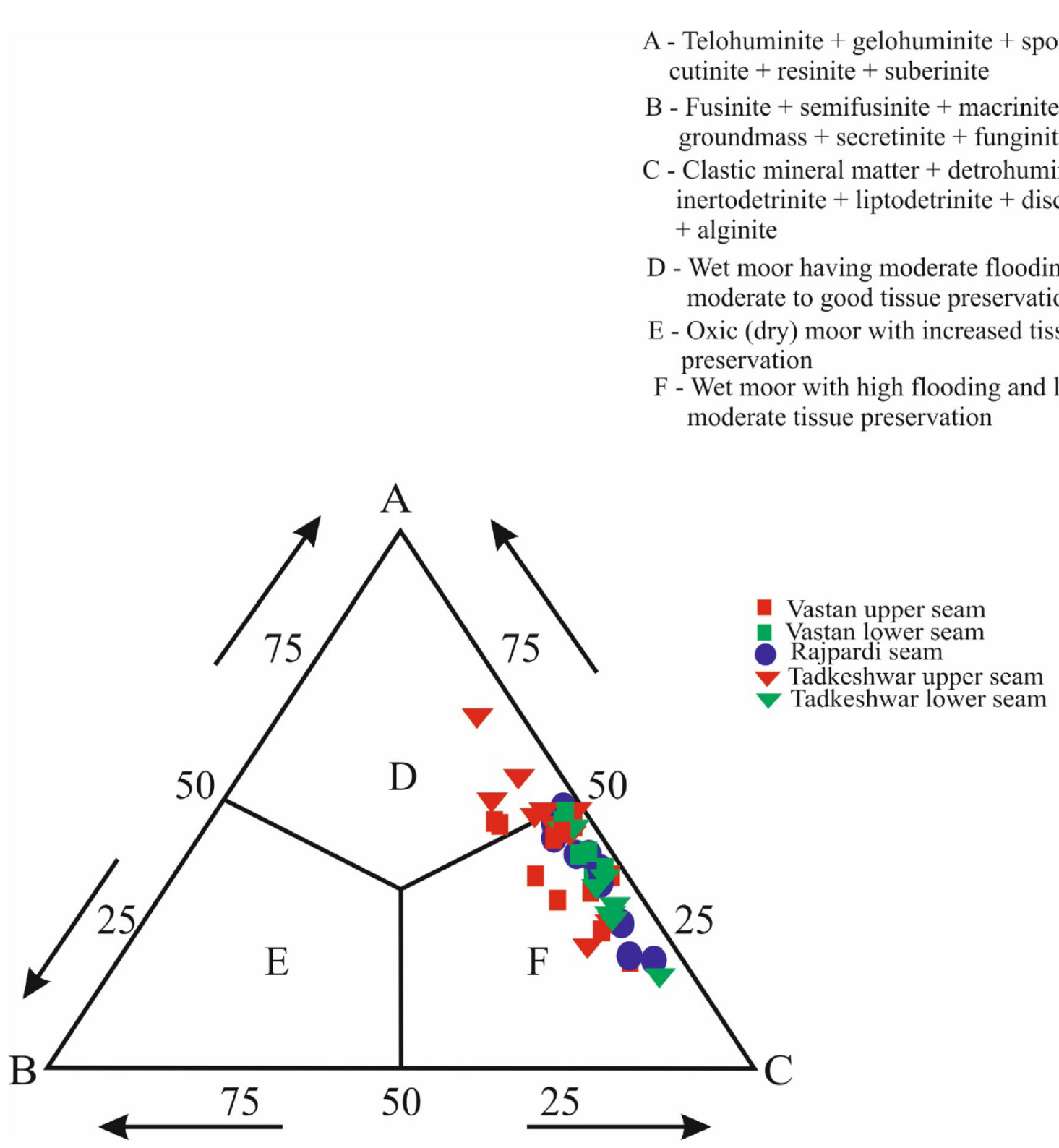

Fig. 8 Peat forming environment of lignites of Cambay Basin, Gujarat, based on macerals and mineral matter (after Singh et al. 2012a)

lignite sequence, Sahni et al. (2006) have also shown that there was a large supply of fresh water into the bay. According to Singh et al. (2016b), a similar depositional setting also existed during the formation of the nearly located lignite deposits of Rajasthan. Further, based on petrographic facies models, their study point out that the Barmer lignites of Rajasthan evolved under wet forest swamp to clastic marsh having telmatic to limno-telmatic condition; there prevailed a moderate rate of subsidence and a very slow fall in ground water table. This also holds well in case of Cambay basin lignites. Further, Vastan lignites and the associated sediments (Cambay Basin) have yielded rich pollen assemblage (Samant and Tapaswi 2000, 2001). Marine ostracods are reported by Bhandari et al. (2005) and marine fish remains and mammalian fossils by Nolf et al. (2006), and Rana et al. (2005a, b, c). Such environment is possible as a result of sea water influx into the peat swamp owing to eustatic rise which has been evidenced by the views of Haq et al. (1987), Hardenbol et al. (1998), Sluijis et al. (2008), and Prasad et al. (2013).

\section{Conclusions}

(1) The Cambay basin of Gujarat comprises of three lignite fields which include Vastan, Rajpardi and Tadkeshwar. Organic petrographic study reveal that all the lignite samples of the Cambay basin consist 
dominantly of huminite maceral group $(71.6 \%-$ $86.3 \%$, mean $77.92 \%$ on $\mathrm{mmf}$ basis) which is followed by liptinite $(10.1 \%-19.3 \%$, mean $14.8 \%$ on $\mathrm{mmf}$ basis) and inertinite $(3.6 \%-11.0 \%$, mean $7.4 \%$ on $\mathrm{mmf}$ basis) maceral groups. The mineral matter is low to moderate in content $(9.0 \%-20.0 \%$, mean $11.8 \%)$.

(2) The lignites of Cambay basin have high GI and low TPI values indicative of a continuous wet condition in the basin and a relatively slow rate of subsidence during the decay of organic matter. Few sections in Tadkeshwar seam suffered relatively drier spells as revealed by moderately high content of inertinite macerals as indicated by the occurrence of funginite which normally thrives in the upper oxygenated peatigenic layer and indicates prevalence of oxic conditions during plant deposition. GI value $>10$ indicates a forest permanently flooded and pronounced degree of degradation which happened on several occasions during the formation of seams in Tadkeshwar, Rajpardi and Vastan seams of the Cambay basin. The petrography based facies models indicate the prevalence of such environmental condition during transgressive phase. However, there existed intermittent fluvial activities giving rise to supratidal flood plain which are reflected in the form of associated carbonaceous shales in the basin.

Open Access This article is distributed under the terms of the Creative Commons Attribution 4.0 International License (http://crea tivecommons.org/licenses/by/4.0/), which permits unrestricted use, distribution, and reproduction in any medium, provided you give appropriate credit to the original author(s) and the source, provide a link to the Creative Commons license, and indicate if changes were made.

\section{References}

Amijaya H, Littke R (2005) Microfacies and depositional environment of Tertiary Tanjung Enim low rank coal, South Sumatra basin, Indonesia. Int J Coal Geol 61(3-4):197-221

Bajpai S, Kapur VV, Thewissen JGM, Tiwari BN, Das DP, Sharma R, Sarvanna N (2005) Early eocene primates from vastan lignite mine, Gujarat, western India. J Palaeontol Soc India 50:43-54

Balasubramanyan MN (2006) Geology and tectonics of India: an overview, vol 9. International Association for Gondwana Research, Memoir, p 204

Bechtel A, Sachsenhofer RF, Kolcon I, Gratzer R, Otto A, Puttmann W (2002) Organic geochemistry of the Lower Miocene Oberdorf lignite (Styrian Basin, Austria); its relation to petrography, palynology and the peleoenvironment. Int J Coal Geol 51:31-57

Bechtel A, Gruber W, Sachsenhofer RF, Gratzer R, Lucke A, Puttmann W (2003) Depositional environment of the Late Miocene Hausruck lignite (Alpine Foreland Basin); insights from petrography, organic geochemistry and stable carbon isotopes. Int J Coal Geol 53:153-180

Bechtel A, Widera M, Sachsenhofer RF, Gratzer R, Lücke A, Woszczyk M (2007a) Biomarker and stable carbon isotope systematics of fossil wood from the second Lusatian lignite seam of the Lubstów deposit (Poland). Org Geochem 38:1850-1864

Bechtel A, Reischenbacher D, Sachsenhofer RF, Gratzer R, Lücke A, Püttmann W (2007b) Relations of petrographical and geochemical parameters in the middle Miocene Lavanttal lignite (Austria). Int J Coal Geol 70:325-349

Bechtel A, Gratzer R, Sachsenhofer RF, Gusterhuber J, Lücke A, Püttmann W (2008) Biomarker and carbon isotope variation in coal and fossil wood of Central Europe through the Cenozoic. Palaeogeogr Palaeoclimatol Palaeoecol 262:166-175

Bhandari A, Singh H, Rana RS (2005) A note on the occurrence of Ostracoda from the Vastan Lignite Mine, Gujarat. J Palaeontol Soc India 50:141-146

BIS (2003) Methods of test for coal and coke (2nd revision of IS: 1350). Part I, proximate analysis. Bureau of Indian Standard, pp 1-29

Biswas SK (1987) Regional tectonic framework, structure and evolution of the western marginal basins of India. Tectonophysics 135:307-327

Biswas SK (1992) Tertiary stratigraphy of Kutch. J Palaeontol Soc India $37: 1-29$

Cabrera L, Hagemann HW, Pickel W, Sáez A (1995) The coalbearing, Cenozoic As Pontes Basin (northwestern Spain): geological influence on coal characteristics. Int J Coal Geol 27:201-226

Calder JH (1993) The evolution of a ground-water influenced (Westphalian B) peat-forming ecosystem in a piedmont setting: the no. 3 seam, Springhill coalfield, Cumberland Basin, Nova Scotia. In: Cobb JC, Cecil CB (eds) Modern and ancient coalforming environments. Geological Society of America, Special Paper, Boulder, pp 153-180

Calder JH, Gibbing MR, Mukhopadhay PK (1991) Peat formation in a Westphalian B piedmont setting, Cumberland Basin, Nova Scotia: implication for the maceral-based interpretation of rheotrophic and raised paleomires. Bulletin de la Societe Geologigue de France 162(2):283-298

Chatterjee S, Bajpai S (2016) India's northward drift from Gondwana to Asia during the Late Cretaceous-Eocene. Proc Indian Natl Sci Acad 82(3):479-487

Cohen AD, Spackman W (1972) Methods in peat petrology and their application to reconstruction of paleoenvironments. Geol Soc Am Bull 83(1):129-142

Cohen AD, Spackman W, Raymond R (1987) Interpreting the characteristics of coal seams from chemical, physical and petrographic studies of peat deposits. In: Scott AC (ed) Coal and Coal-bearing strata: recent advances. The geological society special publication no. 32. Blackwell, Oxford, pp 107-126

Collinson ME, Scott AC (1987) Implications of vegetational change through the geological record on models of coal-forming environments. In: Scott AC (ed) Coal and Coal-Bearing Strata: Recent Advances. Geological society of America, Boulder, pp 67-85

Crosdale PJ (1993) Coal maceral ratios as indicators of environment of deposition: do they work for ombrogenous mires? An example from the Miocene of NewZealand. Org Geochem 20(6):797-809

Dai S, Ren D, Li S, Zhao L, Zhang Y (2007) Coal facies evolution of the main minable coal-bed in the Heidaigou Mine, Jungar Coalfield, Inner Mongolia, northern China. Sci China D Earth Sci 50(Supp. II):144-152

Dehmer J (1995) Petrological and organic geochemical investigation of recent peats with known environments of deposition. Int $\mathbf{J}$ Coal Geol 28(2-4):111-138

Deng XL, Sun YZ (2011) Coal petrological characteristics and coal facies of no.11 seam from the Antaibao mine, Ningwu coalfield, China. Energy Explor Exploit 29(3):313-324

Diessel CFK (1986) On the correlation between coal facies and depositional environments. In: Proceeding 20th symposium of 
Department Geology, University of New Castle, New South Wales, pp 19-22

Diessel CFK (1992) Coal bearing depositional system. Springer, New York, p 721

Dutta S, Mathews RP, Singh BD, Tripathi SKM, Singh A, Saraswati PK, Banerjee S, Mann U (2011) Petrology, palynology and organic geochemistry of Eocene lignite of Matanomadh, Kutch Basin, western India: implications to depositional environment and hydrocarbon source potential. Int J Coal Geol 85:91-102

Flores D (2002) Organic facies and depositional palaeoenvironment of lignites from Rio Maior Basin (Portugal). Int J Coal Geol 48(3-4):181-195

Garg R, Ateequzzaman K, Prasad V, Tripathi SKM, Singh IB, Jauhri AK, Bajpai S (2008) Age diagnostic dinoflagellate cysts from the lignite-bearing sediments of the Vastan lignite mine, Surat District, Gujarat, western India. J Palaeontol Soc India 53:99-105

GMDC (1989) (Gujarat Mineral Development Corporation Ltd.) Mine report-exploration in Tarkeshwar area (Surat), prepared by Mineral Exploration Corporation Ltd., pp 1-377 (Unpublished)

Grady WC, Eble CF, Neuzil SG (1993) Brown coal maceral distributions in a modern domed tropical Indonesian peat and a comparison with maceral distributions in Middle Pennsylvanianage Appalachian bituminous coal beds. Geol Soc Am Spec Pap 286:63-82

GSI (2012) Geological and Mineral Map of Gujarat, Daman and Diu (Published under the Direction of the Director General, Geological Survey of India; Government of India Copyright 2012)

Hagemann HW, Wolf M (1987) New interpretations of the facies of the Rhenish brown coal of West Germany. Int J Coal Geol $7: 337-348$

Haq BU, Hardenbol J and Vail PR (1987) Chronology of fluctuating sea levels since the Triassic. Science 235:1156-1167

Hardenbol J, Thierry J, Farley MB, Jacquin T, de Graciansky PC, Vail PR (1998) Mesozoic and Cenozoic sequence chronostratigraphic framework of European basins. In: de Graciansky PC, Hardenbol J, Jacquin T, Vail PR (eds) Mesozoic and Cenozoicsequence stratigraphy of European basins, vol 60. SEPM Special Publication, New York, pp 763-786

Hawke MI, Martini IP, Stasiuk LD (1996) Petrographic characteristics of selected Ontario Peats: possible modern analogues for coals. In: 13th Annual meeting TSOP, Abstracts and Program. Southern Illinois University, Carbondale Illinois, pp 22-23

Hoekel A (1989) On the plate tectonic setting of the coal deposits of Indonesia and the Phillippines. Mitteilungen des Österreichische Geologische Gesellschaft 82:119-133

Home JC, Ferm FT, Caruccio FT and Baganz BP (1978) Depositional models in coal exploration and planning in Appalachian Region. Bulletin AAPG 62:2379-2411

ICCP (2001) The new inertinite classification (ICCP System 1994). Fuel 80:459-471

Iordanidis A, Georgakopoulos A (2003) Pliocene lignites from Apofysis mine, Amynteo basin, Northwestern Greece: petrographical characteristics and depositional environment. Int $\mathrm{J}$ Coal Geol 54:57-68

Jasper K, Hartkopf-Froder C, Flajs G, Littke R (2010) Evolution of Pennsylvanian (Late Carboniferous) peat swamps of the Ruhr Basin, Germany: comparison of palynological, coal petrographical and organic geochemical data. Int $\mathrm{J}$ Coal Geol 83(4):346-365

Jennifer MK, O'Keefe JMK, Bechtel A, Christanis K, Dai S, DiMichele WA, Eble CF, Esterle JS, Mastalerz M, Raymond AL, Valentim BV, Wagner NJ, Ward CR, Hower JC (2013) On the fundamental difference between coal rank and coal type. Int $\mathrm{J}$ Coal Geol 118:58-87
Joshi VK (2007) Pages of past environment entombed in a mine. www.boloji.com/environment/121.htm

Kalkreuth WD, Marchioni DL, Calder JH, Lamberson MN, Naylor RD, Paul J (1991) The relationship between coal petrography and depositiona environments from selected coal basins in Canada. In: Kalkreuth WD, Bustin RM, Cameron AR (eds) Recent advances in organic petrology and geochemistry. A Symposium honouring Dr. P. Hacquebard. International Journal of Coal Geology, vol 19, pp 21-76

Kuder T, Kruge MA, Shearer JC, Miller SL (1998) Environmental and botanical controls on peatification - a comparative study of two New Zealand restiad bogs using Py-GC/MS, petrography and fungal analysis. Int J Coal Geol 37:3-27

Lamberson MN, Bustin RM, Kalkreuth W (1991) Lithotype (maceral) composition and variation as correlated with paleo-wetland environment, Gates Formation, Northeastern British Columbia, Canada. Int J Coal Geol 18:87-124

Lin MY, Tian L (2011) Petrographic characteristics and depositional environment of the No. 9 Coal (Pennsylvanian) from the Anjialing Mine, Ningwu Coalfield, China. Energy Explor Exploit 29(2):197-204

Mathur LP, Rao KLN, Chaube AN (1968) Tectonic framework of the Cambay Basin, India. Bull Oil Nat Gas Comm 51:7-28

Mayr C, Lücke A, Maidana NI, Wille M, Haberzettl T, Corbella H, Ohlendorf C, Schäbitz F, Fey M, Jansen S, Zolitschka B (2009) Isotopic and geochemical fingerprints of lacustrine organic matter sources reflect environmental changes during the last 16,000 years in semi-arid Patagonia. J Paleolimnol 42:81-102

Mc Cann T (2010) Chenier plain sedimentation in the Paleogene of western India. Zeitschrift der Deutschen Gesellschaft für Geowissenschaften 161(3):335-351

Moore TA, Shearer JC (2003) Peat/coal type and depositional environment-are they related? Int J Coal Geol 56(3-4):233-252

Neavel RC (1966) Sulfur in coal; its distribution in the seam and in mine products, Ph.D. thesis, Penn State University, p 332

Nolf D, Rana RS, Singh H (2006) Fish Otoliths fromthe Ypresian (Early Eocene) of Vastan, Gujarat, India. Bulletine de I'nstitute de royal des sciences naturelles de Belgique, sciences dela Terre 76:105-118

Pandey J, Singh NP, Krishna BR, Sharma DD, Paraikh AK, Nath SS (1993) Lithostratigraphy of Indian petroliferous basins document-III, Cambay Basin. KDM Institute of Petroleum Exploration ONGC, Allied Printers, Dehradun, pp 1-166

Pareek HS (1981) Petrology of Kalol lignite, Cambay basin, Gujarat. In: Symposium on three decades of development in Petrology, Mineralogy and Petrochemistry in India, Geological Survey of India, pp 106-107

Petersen HI (1993) Petyrographic facies analysisof Lower and Middle Jurassic coal seams on the island of Bomholm, Denmark. Int J Coal Geol 22(3-4):189-216

Pickel W, Kus J, Flores D, Kalaitzidis S, Christanis K, Cardott BJ, Misz-Kennan M, Rodrigues S, Hentschel A, Hamor-Vido M, Crosdale P, Wagner N (2017) Classification of liptinite-ICCP system 1994. Int J Coal Geol 169:40-61

Prasad V, Thakur B, Kapur V, Singh IB, Singh A, Bajpai S, Garg R, Saravanan N (2013) Palynofacies and sedimentology-based high-resolution sequence stratigraphy of the lignite-bearing muddy coastal deposits (early Eocene) in the Vastan Lignite Mine, Gulf of Cambay, India. Facies 59:737-761

Rana RS, Kumar K, Singh H (2005a) Vertebrate fauna from the subsurface Cambay shale (Lower Eocene), Vastan Lignite Mine, Gujarat, India. Curr Sci 87:1726-1733

Rana RS, Kumar K, Singh H, Rose KD (2005b) Lower vertebrates from the late Palaeocene-earliest Eocene Akli Formation Giral Lignite Mine Barmer District western India. Curr Sci 89:1606-1613 
Rana RS, Singh H, Sahni A, Rose KD, Saraswati PK (2005c) Early Eocene chiropterans from a new mammalian assemblage (Vastan Lignite Mine, Gujarat, western peninsular margin): oldest known bats from Asia. J Palaeontol Soc India 50:93-100

Rao KLN (1969) Lithostratigraphy of paleogene succession of southern Cambay Basin, India. Bull ONGC 6:24-37

Rao MR, Sahni A, Rana RS, Verma P (2013) Palynostratigraphy and depositional environment of Vastan Lignite Mine (Early Eocene), Gujarat, western India. J Earth Syst Sci 122:289-307

Sahni A, Saraswati PK, Rana RS, Kishor K, Singh H, Alimohammadian H, Sahni N, Rose KD, Singh L, Smith T (2006) Temporal constraints and depositional paleoenvironmnets of the Vastan lignite sequences, Gujarat: analogy for Cambay shale hydrocarbon source rock. Indian J Petrol Geol 15:1-20

Samant B, Tapaswi PM (2000) Fungal remains from Surat Lignite deposits (Early Eocene) of Gujarat, India. Gondwana Geol Mag 15:25-30

Samant B, Tapaswi PM (2001) Paleontology of the Early Eocene Surat Lignite deposits of Gujarat, India. J Palaeontol Soc India 46:121-132

Savard MM, Bégin C, Marion J, Arseneault D, Bégin Y (2012) Evaluating the integrity of $\mathrm{C}$ and $\mathrm{O}$ isotopes in sub-fossil wood from boreal lakes. Palaeogeogr Palaeoclimatol Palaeoecol 348-349:21-31

Saxena RK (1979) Palynology of the Matanomadh Formation in type area, northwestern Kutch, India: part 2, Systematic description of gymnospermous and angiospermous pollen grains. Palaeobotanist 26:130-143

Scott AC (2000) The Pre-Quaternary history of fire. Palaeogeogr Palaeoclimatol Palaeoecol 164(1):281-329

Shearer JC, Clarkson BR (1998) Whangamarino wetland: effects of lowered river levels on peat and vegetation. Int Peat J 8:52-65

Singh PK (2012) Petrological and geochemical considerations to predict oil potential of Rajpardi and Vastan Lignite deposits of Gujarat, Western India. J Geol Soc India 80:759-770

Singh MP, Singh PK (1996) Petrographic characterization and evolution of the Permian coal deposits of the Rajmahal basin, Bihar, India. Int J Coal Geol 29:93-118

Singh BD, Singh A (2003) Petrographic evaluation of lignites from Panandhro field (Kutch Basin), Gujarat. Minetech 24:48-63

Singh A, Singh BD (2005) Petrology of Panandhro lignite deposit, Gujarat in relation to palaeodepositional condition. J Geol Soc India 66:334-344

Singh PK, Singh MP, Singh AK (2010a) Petro-chemical characterization and evolution of Vastan Lignite, Gujarat, India. Int J Coal Geol 82:1-16

Singh PK, Singh MP, Singh AK, Arora M (2010b) Petrographic characteristics of coal from the Lati Formation, Tarakan basin, East Kalimantan. Int J Coal Geol 81:109-116

Singh A, Thakur OP, Singh BD (2012a) Petrographic and depositional characteristics of tadkeshwar lignite deposits (Cambay basin), Gujarat. J Geol Soc India 80:329-340

Singh PK, Singh MP, Singh AK, Naik AS, Singh VK, Singh VK, Rajak PK (2012b) Petrological and geochemical investigations of Rajpardi lignite deposit, Gujarat, India. Energy Explor Exploit 30(1):131-152
Singh PK, Singh MP, Singh AK, Naik AS (2012c) Petrographic and geochemical characterization of coals from Tiru valley, Nagaland, NE India. Energy Explor Exploit 30(2):171-192

Singh PK, Singh MP, Prachiti PK, Kalpana MS, Manikyamba C, Lakshminarayana G, Singh AK, Naik AS (2012d) Petrographic characteristics and carbon isotopic composition of Permian coal: implications on depositional environment of Sattupalli coalfield, Godavari Valley, India. Int J Coal Geol 90-91:34-42

Singh PK, Singh VK, Rajak PK, Singh MP, Naik AS (2016a) Distribution and geochemistry of selected trace elements in the lignites of Cambay Basin, Gujarat, Western India. J Geol Soc India 88:131-146

Singh PK, Rajak PK, Singh MP, Singh VK, Naik AS (2016b) Geochemistry 286 of Kasnau-Matasukh lignites, Nagaur basin, Rajasthan (India). Int J Coal Sci Technol 3:104-122

Sluijs A, Brinkhuis H, Crouch EM, John CM, Handley L, Munsterman D, Bohaty SM, Zachos JC, Reichart GJ, Schouten S, Pancost RD, Sinninghe Damsté JS, Welters LDN, Lotter AF, Dickens GR (2008) Eustatic variations during the PaleoceneEocene greenhouse world. Paleoceanography 23:4216

Styan WB, Bustin RM (1983) Petrography of some Fraser Delta peat deposits: coal maceral and microlithotype precursors in temperate-climate peats. Int J Coal Geol 2(4):321-370

Sudhakar R, Basu DN (1973) A reappraisal of the stratigraphy of southern Cambay Basin. Bull ONGC 10:55-76

Sun YZ, Wang BS, Lin MY (1998) Maceral and Geochemical Characteristics of Coal Seam 1 and Oil Shale 1 in Fault-controlled Huangxian Basin, China. Org Geochem 29(1-3):583-591

Sýkorová I, Pickel W, Christanis M, Wolf K, Taylor GH, Flores D (2005) Classification of huminite, ICCP System 1994. Int J Coal Geol 62:85-106

Taylor GH, Teichmüller M, Davis A, Diessel CFK, Littke R, Robert P (1998) Organic Petrology. Elsevier, Gebrüder Borntraeger, Berlin, p 704

Teichmüller M (1989) The genesis of coal from the viewpoint of coal petrology. In: Lyons PC, Alpern B (eds) Peat and coal: origin, facies and depositional models. Springer, Berlin, pp 1-87

Teichmüller M, Taylor GH, Littke R (1998a) The nature of organic matter-macerals associated minerals. In: Taylor GH, Teichmuller M, Davis A, Diessel CFK, Littke R, Robert P (eds) Organic Petrology. Gebruder Borntraeger, Berlin, p 704

Teichmüller M, Littke R, Taylor GH (1998b) The origin of organic matter in sedimentary rocks. In: Taylor GH, Teichmüller M, Davis A, Diessel CFK, Littke R, Robert P (eds) Organic petrology. Gebruder Borntraeger, Berlin, p 704

Teichmüller M, Littke R, Taylor GH (1998c) The origin of organic matter in sedimentary rocks. In: Taylor GH, Teichmüller M, Davis A, Diessel CFK, Littke R, Robert P (eds) Organic petrology. Gebruder Borntraeger, Berlin, p 704

Thakur OP, Singh A, Singh BD (2010) Petrographic characterization of Khadsaliya Lignites, Bhavnagar District, Gujarat. J Geol Soc India 76:40-46

Wust RAJ, Hawke MI, Bustin RM (2001) Comparing maceral ratios from tropical peatlands with assumption from coal studies; do classic coal petrographic interpretation methods have to be discarded. Int J Coal Geol 48:115-132 